\title{
Product platform design and customization: Status and promise
}

\section{TIMOTHY W. SIMPSON}

Departments of Mechanical and Nuclear and Industrial and Manufacturing Engineering, Pennsylvania State University, University Park, Pennsylvania 16802, USA

(Received February 13, 2003; ACCEPTEd August 27, 2003)

\begin{abstract}
In an effort to improve customization for today's highly competitive global marketplace, many companies are utilizing product families and platform-based product development to increase variety, shorten lead times, and reduce costs. The key to a successful product family is the product platform from which it is derived either by adding, removing, or substituting one or more modules to the platform or by scaling the platform in one or more dimensions to target specific market niches. This nascent field of engineering design has matured rapidly in the past decade, and this paper provides a comprehensive review of the flurry of research activity that has occurred during that time to facilitate product family design and platform-based product development for mass customization. Techniques for identifying platform leveraging strategies within a product family are reviewed along with metrics for assessing the effectiveness of product platforms and product families. Special emphasis is placed on optimization approaches and artificial intelligence techniques to assist in the process of product family design and platform-based product development. Web-based systems for product platform customization are also discussed. Examples from both industry and academia are presented throughout the paper to highlight the benefits of product families and product platforms. The paper concludes with a discussion of potential areas of research to help bridge the gap between planning and managing families of products and designing and manufacturing them.
\end{abstract}

Keywords: Mass Customization; Product Family; Product Platform; Product Variety

\section{INTRODUCTION}

Today's highly competitive global marketplace is redefining the way many companies do business. The new form of competitive advantage is mass customization, and is, as Pine (1993a, p. xiii) says, "a new way of viewing business competition, one that makes the identification and fulfillment of the wants and needs of individual customers paramount without sacrificing efficiency, effectiveness, and low costs." In his seminal text on mass customization, Pine (1993a, p. 6) argues that "customers can no longer be lumped together in a huge homogeneous market, but are individuals whose individual wants and needs can be ascertained and fulfilled." He attributes the increasing attention on product variety and customer demand to the saturation of the market and the need to improve customer satisfaction: new

Reprint requests to: Timothy W. Simpson, 329 Leonhard Building, Penn State University, University Park, PA 16802. E-mail: tws8@psu.edu products must be different from what is already in the market and must meet customer needs more completely. Sanderson and Uzumeri (1997, p. 3) add that "the emergence of global markets has fundamentally altered competition as many firms have known it" with the resulting market dynamics "forcing the compression of product development times and expansion of product variety." Findings from studies of the automotive industry (Womack et al., 1990; MacDuffie et al., 1996; Alford et al., 2000) and empirical surveys of manufacturing firms (Chinnaiah et al., 1998; Duray et al., 2000) confirm these trends. Similar themes pervade the text by Wortmann et al. (1997), who examine industry's response in Europe to the "customer-driven" market.

Because many companies typically design new products one at a time, Meyer and Lehnerd (1997, p. 2) have found that the focus on individual customers and products results in "a failure to embrace commonality, compatibility, standardization, or modularization among different products or product lines." Mather (1995, p. 378) finds that "rarely does 
the full spectrum of product offerings get reviewed at one time to ensure it is optimal for the business." The end result is a "mushrooming" or diversification of products and parts that can overwhelm customers (Stalk \& Webber, 1993; Mather, 1995; Huffman \& Kahn, 1998). Nissan, for example, reportedly had 87 different varieties of steering wheels for one of their cars (Chandler \& Williams, 1993). Although offering a wide variety of products has both positive and negative effects (cf., Galsworth, 1994; Anderson \& Pine, 1997; Ho \& Tang, 1998), the proliferation of product variety can incur substantial costs within a company (Lancaster, 1990; Child et al., 1991; Ishii, Juengel, \& Eubanks, 1995). "The imperative today," write Anderson and Pine (1997, p. 3), "is to understand and fulfill each individual customer's increasingly diverse wants and needs-while meeting the coequal imperative for achieving low cost."

Many companies are using product families and platformbased product development to provide sufficient variety for the market while maintaining economies of scale and scope within their manufacturing processes. In general terms, a product family is a group of related products that is derived from a product platform to satisfy a variety of market niches. As Robertson and Ulrich (1998, p. 20) point out, "by sharing components and production processes across a platform of products, companies can develop differentiated products efficiently, increase the flexibility and responsiveness of their manufacturing processes, and take market share away from competitors that develop only one product at a time."

Platform-based product development offers a multitude of benefits including reduced development time and system complexity, reduced development and production costs, and improved ability to upgrade products. Platforms also promote better learning across products and can reduce testing and certification of complex products such as aircraft (Sabbagh, 1996), spacecraft (Caffrey et al., 2002c), and aircraft engines (Rothwell \& Gardiner, 1990). In the automotive industry, platforms enable greater flexibility between plants and can increase plant usage (sharing underbodies between models can yield a $50 \%$ reduction in capital investment, especially in welding equipment) and can reduce product lead times by as much as 30\% (Muffatto, 1999). Firms using a platform-based product development approach in the automotive industry recently gained a 5.1\% market share per year whereas firms that did not lost 2.2\% (Cusumano \& Nobeoka, 1998).

Methods for platform-based product development have progressed remarkably in the past decade, and this paper provides a comprehensive review of the flurry of research activity that has occurred during that time to facilitate product family design and platform-based product development for mass customization. In the next section, definitions and examples of product families and product platforms are given to set the stage for the discussions that follow. Sections 3 and 4 describe strategies for leveraging product platforms across different market segments and metrics for assessing product platforms, respectively. Sections 5 and 6 review optimization approaches and artificial intelligence (AI) techniques, respectively, for designing and configuring families of products. The relationship between product platforms and mass customization is examined further in Section 7, and Web-based systems for product platform customization are also discussed. Finally, closing remarks and avenues of future research are outlined in Section 8.

\section{PRODUCT FAMILIES AND PLATFORMS: DEFINITIONS AND EXAMPLES}

There are two basic approaches to product family design (Simpson, Maier, \& Mistree, 2001). The first is a top-down (proactive platform) approach wherein a company strategically manages and develops a family of products based on a product platform and its derivatives. For instance, Sony has strategically managed the development of its Walkman ${ }^{\circledR}$ products using carefully designed product platforms and derivatives (Sanderson \& Uzumeri, 1997). Similarly, Kodak's product platform-based response to Fuji's intro-

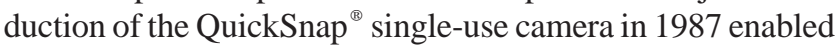
them to develop products faster and more cheaply, allowing them to regain market share and eventually overtake Fuji (Wheelwright \& Clark, 1995). The second is a bottom-up (reactive redesign) approach, wherein a company redesigns or consolidates a group of distinct products to standardize components to improve economies of scale. For example, after working with individual customers to develop $100+$ lighting control products, Lutron redesigns its product line around 15-20 standard components that can be configured into the same $100+$ models from which customers could initially choose (Pessina \& Renner, 1998). Black \& Decker (Lehnerd, 1987) and John Deere (Shirley, 1990) have benefited from similar redesign efforts to reduce variety in their motor and valve lines, respectively.

The key to success in either approach is the product platform from which the product family is derived. A product platform can be either narrowly or broadly defined as

- "a set of common components, modules, or parts from which a stream of derivative products can be efficiently developed and launched" (Meyer \& Lehnerd, 1997, p. 7);

- "a collection of the common elements, especially the underlying core technology, implemented across a range of products" (McGrath, 1995, p. 39); and

- "the collection of assets [i.e., components, processes, knoweledge, people and relationships] that are shared by a set of products" (Robertson \& Ulrich, 1998, p. 20).

As an example, a platform at Volkswagen consists of the floor group, drive system, and running gear, along with the unseen part of the cockpit as shown in Figure 1. This platform is shared across several models as well as all of its brands (i.e., Volkswagen, Audi, Seat, and Skoda). According to Bremmer (1999), Volkswagen owned three of the six auto- 


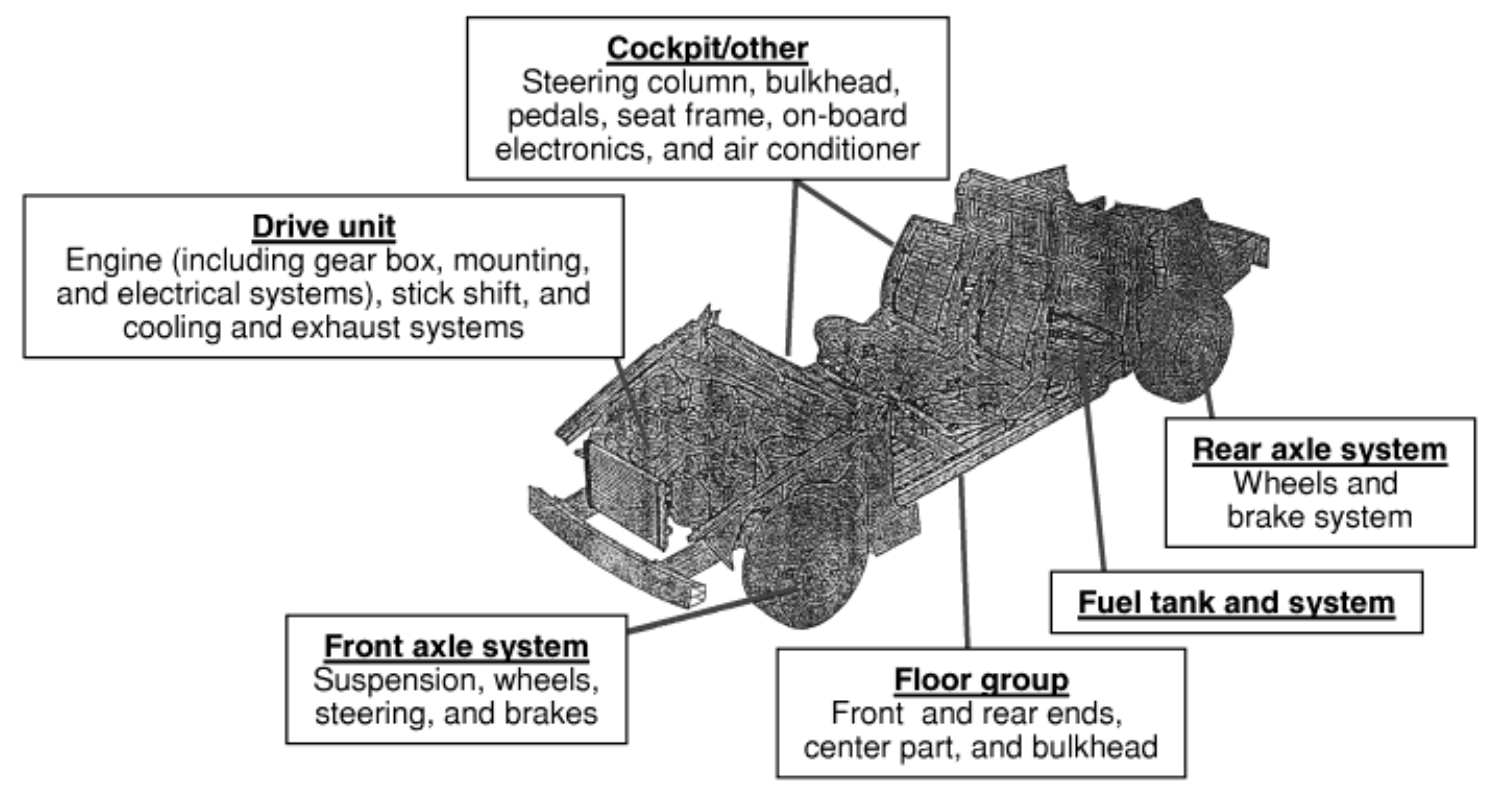

Fig. 1. Volkswagen's platform definition. Adapted from Wilhelm (1997).

motive platforms that successfully achieved production volumes over 1 million in 1999. The number of million-unit platforms is expected to reach 16 by 2004, with Volkswagen leading the way with its A04 and A4/A5 platforms.

The prominent approach to platform-based product development, be it top-down or bottom-up, is through the development of a module-based product family, wherein product family members are instantiated by adding, substituting, and/or removing one or more functional modules from the platform. An alternative approach is through the development of a scale-based product family, wherein one or more scaling variables are used to "stretch" or "shrink" the platform in one or more dimensions to satisfy a variety of market niches. Examples and methods for module-based product family design are described in the next section, followed by examples of scale-based product families in Section 2.2.

\subsection{Module-based product families}

There are numerous examples of module-based product families in the literature; some of the more frequently quoted examples follow.

- Sony builds all of its Walkmans ${ }^{\circledR}$ around key modules and platforms and uses modular design and flexible manufacturing to produce a variety of quality products at low cost, which allowed them to introduce $250+$ models in the United States in the 1980s (Sanderson \& Uzumeri, 1997).

- Nippondenso Co. Ltd. makes an array of automotive components for a variety of automotive manufacturers using a combinatoric strategy that involves several different modules with standardized interfaces; for instance, 288 different types of panel meters can be assembled from 17 standardized subassemblies (Whitney, 1993).

- Hewlett Packard successfully developed several of their ink jet and laser jet printers around modular components to gain the benefits of postponing the point of differentiation in their manufacturing and assembly processes (Feitzinger \& Lee, 1997).

- Bally Engineering Structures offers an almost infinite variety of environmentally controlled structures that can be readily assembled from one basic modular component - the pre-engineered panel — that can be produced in a variety of shapes and sizes and customized with options, attachments, and finishes to fit into any size structure (Pine, 1993b).

These successful examples resulted from careful attention to customer needs and the underlying product architecture in the family. Ulrich (1995, p. 420) defines the product architecture as "(1) the arrangement of functional elements; (2) the mapping from functional elements to physical components; (3) the specification of the interfaces among interacting physical components." A product architecture is classified as either modular, if there is a one to one or many to one mapping of functional elements to physical structures, or integral, if a complex or coupled mapping of functional elements to physical structures and/or interfaces exists. For example, personal computers (PCs) are highly modular. Baldwin and Clark (2000) trace the development of the IBM's System/360, the first modular computer family. Automotive architectures, on the other hand, are predominantly integral (cf. Siddique et al., 1998; Muffatto, 1999), but modularity has become a major strategic focus for future 
product development within many automotive companies (Kobe, 1997; Shimokawa et al., 1997; Cusumano \& Nobeoka, 1998). For instance, Volkswagen's Golf II comprises several modules to facilitate assembly (see Fig. 2a), and the rolling chassis module produced by the Dana Corporation (Fig. 2b) saved DaimlerChrysler nearly \$700 million when developing their new Dodge Dakota facility (Kimberly, 1999). The rolling chassis module consists of brake, fuel, steering, and exhaust systems; suspension; and drive-line assembled to the frame. It is the largest, most complex module provided by a supplier, accounting for $25 \%$ of the vehicle content.

Modularity is an important topic in many product design textbooks (see, e.g., Pahl \& Beitz, 1996; Ulrich \& Eppinger, 2000; Otto \& Wood, 2001) and is the sole focus in several texts (Ericsson \& Erixon, 1999; O'Grady, 1999; Baldwin \& Clark, 2000). Approaches for developing modular product architectures and module-based product families abound in the engineering design literature. For instance, Mattson and Magleby (2001) discuss concept selection techniques for managing modular product development in the early stages of design. Wood and his coauthors (McAdams et al., 1999; Stone et al., 2000b; McAdams \& Wood, 2002) present a methodology for representing a functional model of a prod-

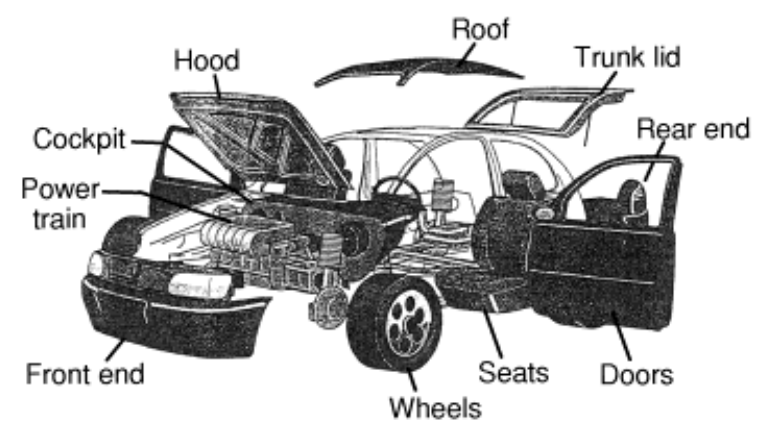

(a) Cockpit Module (Wilhelm, 1997)

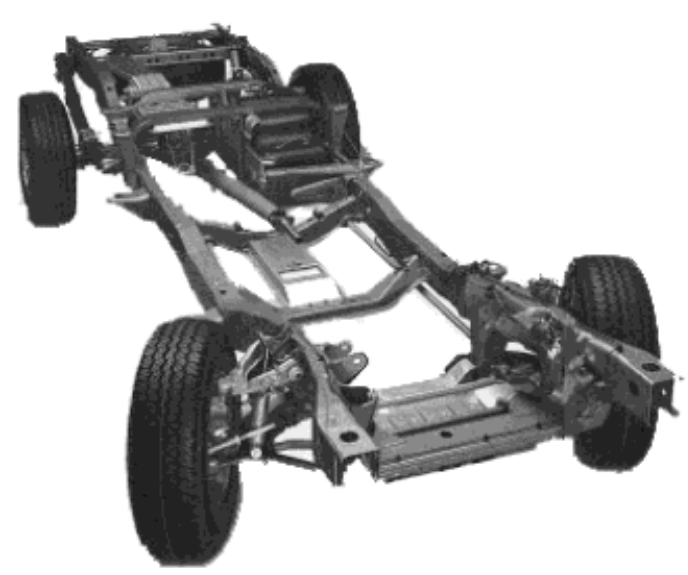

(b) Rolling Chassis Module (Kimberly, 1999)

Fig. 2. (a) Modules in the Golf II. Adapted from Wilhelm (1997). (b) A rolling chassis module. Adapted from Kimberly (1999). uct in a quantitative manner to assist in developing product architectures and facilitate the identification of a core set of modules for a product family. As part of their work, Stone et al. $(2000 a)$ present a heuristic method to identify modules for these product architectures; heuristics to identify functional and variational modules within a product family are introduced by Zamirowksi and Otto (1999). Their work is foundational to the methods for developing modular product architectures developed by Otto and his coauthors (Dahmus et al., 2001; Otto, 2001; Sudjianto \& Otto, 2001).

A method for incorporating customer demand into the development of the modular product architecture is discussed in Yu et al. (1999), and a method for assessing value in a module-based product family using real options concepts in the presence of uncertainty has also been developed (Gonzalez-Zugasti et al., 2001). Sundgren (1999) proposes a method for managing interfaces between modules within a product family after studying several product family development projects in the Swedish manufacturing industry over a period of 3 years; a method for developing robust interfaces for modular products is also introduced in Blackenfelt and Sellgren (2000). Comparisons of methods for modularizing product architectures can be found in Guo and Gershenson (2003) and Holtta and Salonen (2003), and researchers have investigated modular design approaches specifically for electronic products (Tseng \& Jiao, 1997b), digital circuits (Kusiak \& Huang, 1997), and mechatronics products (Huang \& Kusiak, 1999). Finally, Schilling (2000) is developing a general theory of modular systems based on causal models developed from studying systems research in many engineering and nonengineering disciplines.

Modularity also plays a key role in product evolution, upgradeability, and retirement (Ishii, Lee, \& Eubanks, 1995). Zhang et al. (2001) study the impact of modularity on product retirement costs, and life cycle cost issues associated with modular product architectures are discussed in Ulrich (1995), Riitahuta and Andreasen (1999), and Dahmus and Otto (2001). Meanwhile, Newcomb et al. (1998) present a decomposition algorithm to partition architectures into modules based on different life cycle viewpoints, whereas both Coulter et al. (1998) and Umeda et al. (1999) have proposed methodologies for designing modules for evolving families of products subject to life cycle concerns. The impact of modularity on component reuse is discussed in Kimura et al. (2001), and Allen and Carlson-Skalak (1998) develop a methodology for designing modular products that involves identifying and reusing modules from previous generations of products. Similarly, Martin and Ishii (2002) consider multiple generations of products when presenting their approach for designing modular product platform architectures. Their approach is one of several that uses Quality Function Deployment (QFD) to help identify modules within a product family (Cohen, 1995; Erixon, 1996; Ericsson \& Erixon, 1999; Sand et al., 2002). Erixon (1996) has extended QFD into Modular Function Deployment ${ }^{\mathrm{TM}}$, a five-step process that utilizes the Module Identification Matrix ${ }^{\mathrm{TM}}$ to help 
generate module concepts (see also, Ericsson \& Erixon, 1999); Huang and Kusiak (1998) introduce a similar modularity matrix. Techniques for clustering modules based on functional requirements using design structure matrices are discussed in Suh (1990), Pimmler and Eppinger (1994), Blackenfelt (2000a) Stake and Blackenfelt (2000), Kusiak (2002), and Sharman et al. (2002). Optimization-based approaches and AI techniques for configuring and sizing modules are discussed in Sections 5 and 6, respectively.

\subsection{Scale-based product families}

As stated previously, scale-based product families are developed by scaling one or more variables to "stretch" or "shrink" the platform and create products whose performance varies accordingly to satisfy a variety of market niches. Although some consider scale-based product families to be a subset of module-based product families (see, e.g., Fujita \& Yoshida, 2001), platform scaling is a common strategy employed in many industries. For example:

- Honda developed an automobile platform that can be stretched in both width and length to realize a "world car," which was developed after failing to satisfy the Japanese and American markets with a single platform (Naughton et al., 1997).

- Boeing developed many of its commercial airplanes by "stretching" the aircraft to accommodate more passengers, carry more cargo, or increase flight range (Sabbagh, 1996).

- Rolls Royce scaled its RTM322 aircraft engine by a factor of 1.8, as shown in Figure 3, to realize a family of engines with different shaft horsepower and thrust (Rothwell \& Gardiner, 1990).

A frequently quoted example of a successful scale-based product platform is Black \& Decker's universal electric motor. According to Lehnerd (1987), in the 1970s, Black \&
Decker developed a family of universal motors for its power tools in response to a new safety regulation: double insulation. Prior to that, they used different motors in each of their 122 basic tools with hundreds of variations. Through redesign and standardization of the product line, they were able to produce all of their power tools using a line of motors that varied only in the stack length and the amount of copper wrapped within the motors. As a result, all of the motors could be produced on a single machine with stack lengths varying from 0.8 in to $1.75 \mathrm{in}$, and power output ranging from 60 to $650 \mathrm{~W}$. By paying attention to standardization and exploiting platform scaling around the motor stack length, material costs dropped from $\$ 0.77$ to $\$ 0.42$ per motor while labor costs fell from $\$ 0.248$ to $\$ 0.045$ per motor, yielding an annual savings of $\$ 1.82 \mathrm{M}$ per year. Tool costs decreased by as much as $62 \%$, boosting sales, increasing production volumes, and further improving savings. Furthermore, new designs were developed using standardized components such as the redesigned motor, which allowed products to be introduced, exploited and retired with minimal expense related to product development. This electric motor example has served as a test problem for several optimization-based approaches for product family design as noted in Section 5. Meanwhile, the idea of sharing components across different market segments (e.g., power tools, lawn tools) leads us to the topic of platform leveraging.

\section{PLATFORM LEVERAGING STRATEGIES}

Regardless of whether the platform is modular or scalable, the basic development strategy within any product family is to leverage the product platform across multiple market segments or niches. Early attempts at mapping the evolution of a product family based on extensions and upgrades to a product platform can be found in Wheelwright and Sasser (1989) and Meyer and Utterback (1993), but it was not until Meyer (1997) introduced the market segmentation

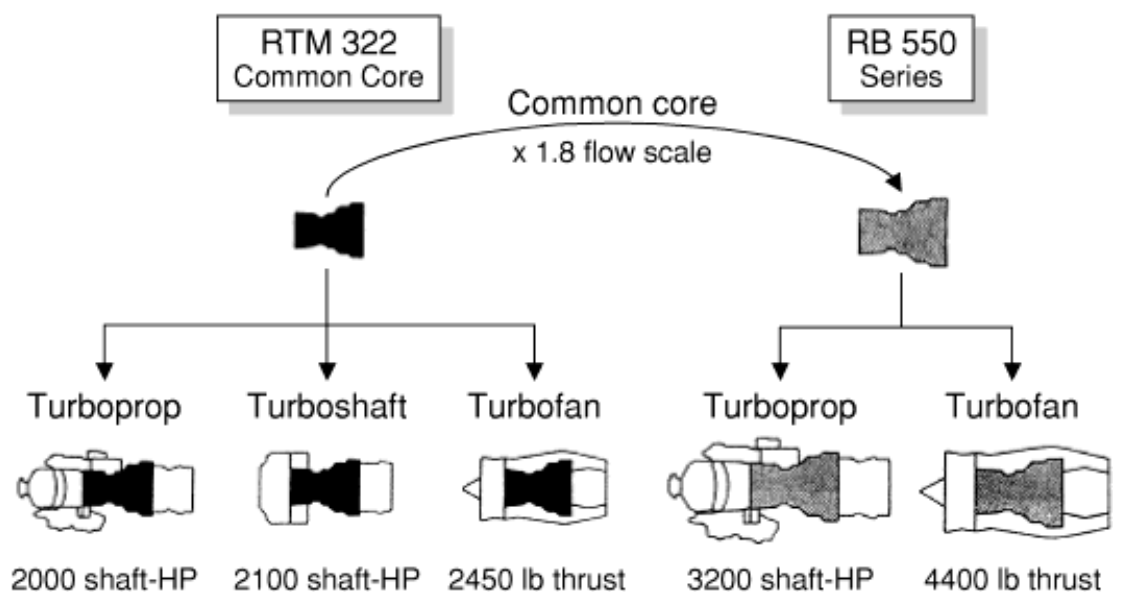

Fig. 3. A family of scale-based aircraft engines; HP, horsepower. Adapted from Rothwell and Gardiner (1990). 
grid that platform leveraging strategies were clearly articulated. As shown in Figure 4, market segments are plotted horizontally in the grid while price/performance tiers are plotted vertically; each intersection of a market segment with a price/performance tier constitutes a market niche that is served by one or more of a company's products. Three platform leveraging strategies can be identified within the grid as shown in Figure 4: horizontal leveraging, vertical leveraging, and the beachhead approach, which combines both. Meyer and Lehnerd (1997) discuss the advantages and drawbacks of each leveraging approach, and examples of market segmentation grids can be found in Caffrey et al. (2002b) for spacecraft and avionics systems and in Meyer and Lehnerd (1997) for computers, data storage systems, power tools, and office furniture.

The market segmentation grid is useful for both platform development (i.e., as part of a top-down approach to product family design), as well as product family consolidation (i.e., as part of a bottom-up approach). For instance, Farrell and Simpson (2003) use the market segmentation grid to identify potential platform leveraging strategies for a line of flow control valves using historical sales data. Although most horizontal leveraging strategies take advantage of modular platforms, the relationship between vertical leveraging strategies and scalable platforms is discussed in (Simpson, Maier, \& Mistree, 2001). Finally, Meyer describes adaptations of the market segmentation grid for platform-based development approaches to nonassembled products (Meyer $\&$ Dalal, 2002) and the design and renewal of services

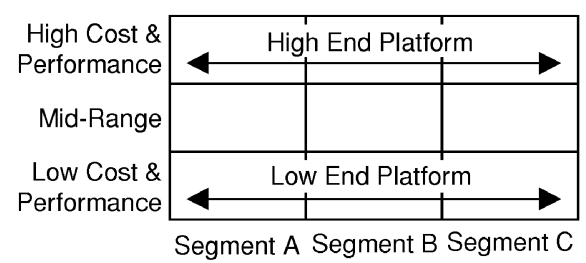

(a) Horizontal Leveraging

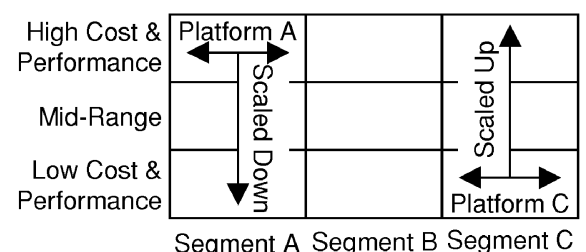

(b) Vertical Leveraging

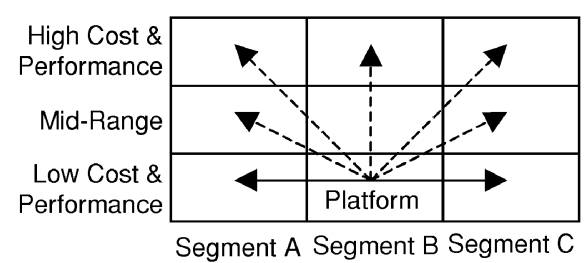

(c) Beachhead Approach

Fig. 4. Platform leveraging strategies. Adapted from Meyer (1997).
(Meyer \& DeTore, 2001). Metrics for measuring the success of platforms and platform leveraging strategies are discussed next.

\section{METRICS FOR PRODUCT PLATFORMS AND PRODUCT FAMILIES}

An important measure of success of a product platform is how quickly and cheaply new products can be developed from it. To help determine when to renew or refocus product platform efforts, Meyer et al. (1997) introduced metrics for platform efficiency and effectiveness. Platform efficiency assesses how much it costs to develop derivative products relative to how much it costs to develop the product platform within the product family. Platform effectiveness measures the ratio of the revenue a product platform and its derivatives create to the cost required to develop them. A similar approach is taken in Schellhammer and Karandikar (2001), wherein a project ranking index, which combines an investment index and a revenue index, is introduced to assist in project planning. Their approach extends the aggregate project planning concepts of Wheelwright and Clark (1992) for managing platform projects, derivative projects, breakthrough projects, advanced research and development projects, and partnership projects and alliances.

During product platform design, much of the focus revolves around the trade-off between commonality and distinctiveness: designers must balance the commonality of the products in the family with the individual performance (i.e., distinctiveness) of each product in the family. For instance, Airbus has enjoyed a competitive advantage over Boeing due to improved commonality, particularly in the cockpit. The A330 cockpit is common to all other Airbus types while Boeing's 767-400 cockpit is common only with the 757. This has enabled the A330-200, a less efficient "shrink" of a larger aircraft, to outsell Boeing's 767400ER, a more efficient "stretch" design of a smaller aircraft (Aboulafia, 2000). Commonality can also adversely impact a company's reputation: in the late 1980s, engineers at Chrysler were accused of having "fallen asleep at the typewriter with our finger stuck on the K key" (Lutz, 1998, p. 17) due to overusage of the K-car platform and lack of distinctive new products.

Despite the potential drawbacks of commonality, numerous indices have been developed to measure commonality in the management science and operations research community (see, e.g., Rutenberg, 1969; Collier, 1981; Baker et al., 1986; Trelevan \& Wacker, 1987; Thomas, 1992; Lee \& Billington, 1994; McDermott \& Stock, 1994; Vakharia et al., 1996; Kim \& Chhajed, 2000). The degree of commonality index proposed by Collier (1981) was one of the first such indices that uses information contained in the company's bills of materials to assess commonality for a single end item, a product family, or an entire product line. Jiao and Tseng (2000) extend Collier's commonality index to create indices for component part commonality and process com- 
monality, overcoming the limitations of his index (cf. Wacker \& Trelevan, 1986). Siddique et al. (1998) propose separate indices for measuring component commonality and connection commonality, applying them to automotive underbodies, which are predominantly integral architectures. Finally, Kota and coauthors (2000) introduce a product line commonality index to capture the level of commonality within a product family based on size and shape, materials and manufacturing processes, and assembly and fastening schemes. Comparisons of these various commonality metrics are lacking in the literature.

Martin and Ishii $(1996,1997)$ also introduced a commonality index similar to Collier's, along with indices for measuring setup costs and the point of product differentiation, which correlate with many of the indirect costs of providing variety. Martin and Ishii (2002) most recently proposed a generational variety index to help identify which components are likely to change over time to meet future market requirements and a coupling index to measure the coupling between these components. The importance of minimizing the coupling in a product architecture has been studied extensively by Suh (1990). A functional similarity index was introduced by McAdams et al. (1999; McAdams \& Wood, 2002) to assist in concept development and modular product design. Finally, indices for measuring the degree of variation within a scale-based product family have also been proposed (Simpson, Seepersad, \& Mistree, 2001; Nayak et al., 2002; Messac et al., 2002b); these indices are useful for product family optimization as discussed next.

\section{OPTIMIZATION-BASED APPROACHES FOR PRODUCT FAMILY AND PRODUCT PLATFORM DESIGN}

Several optimization approaches have been developed within the engineering design community to help determine the best design variable settings for the product platform and individual products within the family; a summary of these approaches is given in Table 1. In looking at the table, the approaches are split evenly between module-based and scalebased product families, while the work by Fujita and Yoshida (2001) specifically targets both. Almost two-thirds of the approaches require specifying the platform a priori to the optimization to reduce the design space and make the problem more tractable. This is not ideal, however, because designers would like to use optimization to explore varying levels of platform commonality to help identify which variables to make common and unique within the family (cf. Simpson \& D'Souza, 2002). More than half of the approaches use multiobjective optimization to accomplish this. Three assumptions are often made when using multiobjective optimization to design a product family:

1. maximizing each product's performance maximizes its demand,
2. maximizing commonality among products minimizes production costs, and

3. resolving the trade-off between assumptions 1 and 2 yields the most profitable product family.

However, without explicitly modeling the market demand for the products in the family and their associated manufacturing costs, these assumptions may lead to suboptimal product families. The universal electric motor example from Lehnerd (1987) employed in Simpson, Maier, and Mistree (2001), Messac et al. (2002b), and Nayak et al. (2002) provides a realistic case of when this can occur. The objective is to design a family of 10 motors based on a scalable platform. The initial formulation scaled the motors around the stack length of the motor (Simpson, Maier, \& Mistree, 2001), but maximizing commonality in the family using two different approaches revealed that the motor platform should be scaled by the radius to maximize performance (Messac et al., 2002b; Nayak et al., 2002). According to Lehnerd (1987), the best choice is stack length, and through discussions with experienced motor designers, production costs, not performance, drive the use of stack length as the scaling variable (Simpson, Maier, \& Mistree, 2001). In the table, note that only about half the approaches integrate manufacturing costs directly within the formulation while less than one-third incorporate market demand/sales. Also, note that the majority of approaches that include costs or sales in their formulation use single objective optimization, rather than multiobjective, where the objective is to either maximize profit or minimize cost.

Although not specifically noted in the table, most of the approaches that incorporate uncertainty in the formulation model it in the market demand and future sales of the products in the family (Seepersad et al., 2000; GonzalezZugasti et al., 2001; Jiang \& Allada, 2001; Allada \& Jiang, 2002; Li \& Azarm, 2002). Uncertainty in customer requirements has also been used to develop robust product platforms. Chang and Ward (1995) were among the first to use robust design techniques to develop a family of products that were insensitive to design changes. Simpson and coauthors use robust design techniques to develop scalebased platforms for General Aviation Aircraft (Simpson et al., 1999), electric motors (Simpson, Maier, \& Mistree, 2001), and absorption chillers (Hernandez et al., 2001). Blackenfelt $(2000 b)$ uses robust design techniques to maximize profit and balance commonality and variety within a family of lift tables.

The number of stages in the optimization approach is another interesting statistic. Single-stage approaches seek to optimize the product platform and corresponding family of products simultaneously while two-stage approaches optimize the platform first and then instantiate the individual products within the family during the second stage; multistage approaches are those that involve more than two stages. Single-stage and two-stage approaches are employed almost equally in the literature, and the reader is referred to the 
Table 1. Summary of engineering optimization approaches for product family design

\begin{tabular}{|c|c|c|c|c|c|c|c|c|c|c|c|c|c|c|c|c|c|c|}
\hline \multirow[b]{3}{*}{ Approach } & \multicolumn{8}{|c|}{ Formulation Details } & & & & & & & & & & \\
\hline & \multirow{2}{*}{$\begin{array}{l}\text { Module- } \\
\text { Based } \\
\text { Family }\end{array}$} & \multirow{2}{*}{$\begin{array}{l}\text { Scale- } \\
\text { Based } \\
\text { Family }\end{array}$} & \multirow{2}{*}{$\begin{array}{c}\text { Specify } \\
\text { Platform } \\
\text { a priori? }\end{array}$} & \multirow{2}{*}{$\begin{array}{c}\text { Single } \\
\text { Objective }\end{array}$} & \multirow[b]{2}{*}{$\begin{array}{c}\text { Multi- } \\
\text { objective }\end{array}$} & \multirow{2}{*}{$\begin{array}{c}\text { Model } \\
\text { Manufac. } \\
\text { Cost? }\end{array}$} & \multirow{2}{*}{$\begin{array}{c}\text { Model } \\
\text { Market } \\
\text { Demand/ } \\
\text { Sales }\end{array}$} & \multirow{2}{*}{$\begin{array}{c}\text { Consider } \\
\text { Uncertainty? }\end{array}$} & \multicolumn{3}{|c|}{ Stages } & \multicolumn{6}{|c|}{ Optimization Algorithm } & \multirow[b]{2}{*}{$\begin{array}{l}\text { Example Product Family } \\
\text { (\# Products in Family) }\end{array}$} \\
\hline & & & & & & & & & $\begin{array}{l}\text { Single } \\
\text { Stage }\end{array}$ & $\begin{array}{l}\text { Two } \\
\text { Stage }\end{array}$ & $\begin{array}{l}\text { Multi- } \\
\text { stage }\end{array}$ & SLP & SQP & NLP & GA $s$ & SA & Other & \\
\hline Allada \& Jiang, 2002 & $\mathrm{x}$ & & $\mathrm{Y}$ & $\mathrm{x}$ & & & $\mathrm{x}$ & $\mathrm{Y}$ & & & $\mathrm{x}$ & & & & & & DP & Generic modular products (3) \\
\hline Blackenfelt, $2000 b$ & $\mathrm{x}$ & & $\mathrm{Y}$ & $\mathrm{x}$ & & $\mathrm{Y}$ & & $\mathrm{Y}$ & $\mathrm{x}$ & & & & & & & & $\mathrm{OA}$ & Lift tables (4) \\
\hline Cetin \& Saitou, 2003 & $\mathrm{x}$ & & & & $\mathrm{x}$ & & & & $\mathrm{x}$ & & & & & & $\mathrm{x}$ & $\mathrm{x}$ & & $\begin{array}{l}\text { Welded automotive } \\
\text { structures (2) }\end{array}$ \\
\hline Chang \& Ward, 1995 & $\mathrm{x}$ & & $\mathrm{Y}$ & $\mathrm{x}$ & & & & $\mathrm{Y}$ & $\mathrm{x}$ & & & & & & & & $\mathrm{OA}$ & Automotive A/C units (6) \\
\hline D'Souza \& Simpson, 2003 & & $\mathrm{x}$ & $\mathrm{Y}$ & & $\mathrm{x}$ & & & & $\mathrm{x}$ & & & & & & $\mathrm{x}$ & & & General Aviation Aircraft (3) \\
\hline Farrell \& Simpson, 2003 & & $\mathrm{x}$ & $\mathrm{Y}$ & $\mathrm{x}$ & & & $\mathrm{x}$ & & & $\mathrm{x}$ & & & & & & & GRG & Flow control valves (16) \\
\hline Fellini et al., 2000 & $\mathrm{x}$ & & $\mathrm{Y}$ & & $\mathrm{x}$ & & & & & $\mathrm{x}$ & & & & $\mathrm{x}$ & & & & Automotive powertrain (3) \\
\hline \multicolumn{19}{|l|}{ Fellini, Kokkolaras, } \\
\hline Michelena, et al., 2002 & & $\mathrm{x}$ & & & $\mathrm{x}$ & & & & & $\mathrm{x}$ & & & $\mathrm{x}$ & & & & & Automotive vehicle frame (2) \\
\hline \multicolumn{19}{|l|}{ Fellini, Kokkolaras, } \\
\hline Papalambros, et al., 2002 & & $\mathrm{x}$ & & & $\mathrm{x}$ & & & & & $\mathrm{x}$ & & & $\mathrm{x}$ & & & & & Automotive vehicle frame (2) \\
\hline Fujita et al., 1998 & $\mathrm{x}$ & & $\mathrm{Y}$ & $\mathrm{x}$ & & $\mathrm{Y}$ & $\mathrm{x}$ & & $\mathrm{x}$ & & & & $\mathrm{x}$ & & & & & Commercial aircraft (2) \\
\hline Fujita et al., 1999 & $\mathrm{x}$ & & & $\mathrm{x}$ & & $\mathrm{Y}$ & & & $\mathrm{x}$ & & & & & & & $\mathrm{x}$ & & TV receiver circuits (6) \\
\hline Fujita \& Yoshida, 2001 & $\mathrm{x}$ & $\mathrm{x}$ & & $\mathrm{x}$ & & $\mathrm{Y}$ & $\mathrm{x}$ & & $\mathrm{x}$ & & & & $\mathrm{x}$ & & $\mathrm{x}$ & & $\mathrm{B} \& \mathrm{~B}$ & Commercial aircraft (4) \\
\hline Gonzalez-Zugasti et al., 2000 & $\mathrm{x}$ & & $\mathrm{Y}$ & & $\mathrm{x}$ & & & & $\mathrm{x}$ & & & & & $\mathrm{x}$ & & & & Interplanetary spacecraft (3) \\
\hline Gonzalez-Zugasti \& Otto, 2000 & $\mathrm{x}$ & & & $\mathrm{x}$ & & $\mathrm{Y}$ & & & $\mathrm{x}$ & & & & & & $\mathrm{x}$ & & & Interplanetary spacecraft (3) \\
\hline Gonzalez-Zugasti et al., 2001 & $\mathrm{x}$ & & $\mathrm{Y}$ & & & $\mathrm{Y}$ & $\mathrm{x}$ & $\mathrm{Y}$ & & $\mathrm{x}$ & & & & $\mathrm{x}$ & & & & Interplanetary spacecraft (3) \\
\hline Hernandez et al., 2001 & & $\mathrm{x}$ & $\mathrm{Y}$ & & $\mathrm{x}$ & $\mathrm{Y}$ & & & & $\mathrm{x}$ & & & & & & $\mathrm{x}$ & & Absorption chillers (8) \\
\hline Hernandez et al., 2002 & & $\mathrm{x}$ & & $\mathrm{x}$ & & & & & & & $\mathrm{x}$ & & & & & & PatS & Universal electric motor (10) \\
\hline Hernandez et al., 2003 & $\mathrm{x}$ & $\mathrm{x}$ & & $\mathrm{x}$ & & $\mathrm{Y}$ & & & & & $\mathrm{x}$ & & & & & & ExS & Pressure vessels (16) \\
\hline Jiang \& Allada, 2001 & $\mathrm{x}$ & & & $\mathrm{x}$ & & $\mathrm{Y}$ & $\mathrm{x}$ & $\mathrm{Y}$ & & $\mathrm{x}$ & & $\mathrm{x}$ & & & & & & Vacuum cleaners (3) \\
\hline Kokkolaras et al., 2002 & $\mathrm{x}$ & & $\mathrm{Y}$ & & $\mathrm{x}$ & & & & & $\mathrm{x}$ & & & & $\mathrm{x}$ & & & & Automotive vehicle frame (2) \\
\hline Li \& Azarm, 2002 & $\mathrm{x}$ & & $\mathrm{Y}$ & $\mathrm{x}$ & $\mathrm{x}$ & $\mathrm{Y}$ & $\mathrm{x}$ & $\mathrm{Y}$ & & $\mathrm{x}$ & & & & & $\mathrm{x}$ & & & Cordless screwdrivers (3) \\
\hline Messac et al., $2002 b$ & & $\mathrm{x}$ & & & $\mathrm{x}$ & & & & & $\mathrm{x}$ & & & & $\mathrm{x}$ & & & & Universal electric motor (10) \\
\hline Messac et al., $2002 a$ & & $\mathrm{x}$ & $\mathrm{Y}$ & & $\mathrm{x}$ & & & & $\mathrm{x}$ & & & & & $\mathrm{x}$ & & & & Universal electric motor (10) \\
\hline Nayak et al., 2002 & & $\mathrm{x}$ & & & $\mathrm{x}$ & & & & & $\mathrm{x}$ & & $\mathrm{x}$ & & & & & & Universal electric motor (10) \\
\hline Nelson et al., 2001 & $\mathrm{x}$ & & $\mathrm{Y}$ & & $\mathrm{x}$ & & & & & $\mathrm{x}$ & & & & $\mathrm{x}$ & & & & Nail guns (2) \\
\hline Ortega et al., 1999 & & $\mathrm{x}$ & & & $\mathrm{x}$ & $\mathrm{Y}$ & & & $\mathrm{x}$ & & & $\mathrm{x}$ & & & & & & Oil filters (5) \\
\hline Rai \& Allada, 2002 & $\mathrm{x}$ & & & & $\mathrm{x}$ & $\mathrm{Y}$ & $\mathrm{x}$ & & & $\mathrm{x}$ & & & & $\mathrm{x}$ & & & & $\begin{array}{l}\text { Elec. screwdriver (3) } \\
\quad \& \text { knife (4) }\end{array}$ \\
\hline Seepersad et al., 2000 & & $\mathrm{x}$ & $\mathrm{Y}$ & & $\mathrm{x}$ & $\mathrm{Y}$ & $\mathrm{x}$ & $\mathrm{Y}$ & $\mathrm{x}$ & & & & & & & $\mathrm{x}$ & & Absorption chillers (8) \\
\hline Seepersad et al., 2002 & & $\mathrm{x}$ & $\mathrm{Y}$ & $\mathrm{x}$ & & $\mathrm{Y}$ & $\mathrm{x}$ & $\mathrm{Y}$ & & $\mathrm{x}$ & & & & & & $\mathrm{x}$ & & Absorption chillers (12) \\
\hline Simpson et al., 1999 & & $\mathrm{x}$ & $\mathrm{Y}$ & & $\mathrm{x}$ & & & & $\mathrm{x}$ & & & $\mathrm{x}$ & & & & & & General Aviation Aircraft (3) \\
\hline Simpson, Maier, \& Mistree, 2001 & & $\mathrm{x}$ & $\mathrm{Y}$ & & $\mathrm{x}$ & & & & & $\mathrm{x}$ & & & & & & & GRG & Universal electric motor (10) \\
\hline Simpson \& D’Souza, 2002 & & $\mathrm{x}$ & & & $\mathrm{x}$ & & & & $\mathrm{x}$ & & & & & & $\mathrm{x}$ & & & General Aviation Aircraft (3) \\
\hline
\end{tabular}

Note: SLP, sequential linear programming; SQP, sequential quadratic programming; NLP, nonlinear programming; GA, genetic algorithm; SA, simulated annealing; DP, dynamic programming; OA, orthogonal array; GRG, generalized reduced gradient; B\&B, branch and bound; PatS, pattern search; ExS, exhaustive search. 
table for examples. Although both approaches are effective at determining the best design variable settings for the product platform and product family, single-stage approaches will yield the best overall performance of the product family because the optimization is not partitioned into two or more stages (cf. Messac et al., 2002a). The dimensionality of single-stage optimization problems, however, is considerably higher than in two-stage approaches, which often leads to many computational challenges (cf. Messac et al., $2002 b$ ). It is also worth noting that a modification to the two-stage approach is introduced by Nelson et al. (2001) and used by Fellini et al. (2000), Fellini, Kokkolaras, Michelena, et al. (2002), and Fellini, Kokkolaras, Papalambros, et al. (2002): the first stage involves individually optimizing each product while the second stage involves optimizing the product family with constraints on performance losses due to commonality. Meanwhile, only two multistage approaches have been developed. First, Hernandez et al. (2002, 2003) develop a multistage optimization approach by viewing the product platform design problem as a problem of access in a geometric space. Second, Allada and Jiang (2002) introduce a dynamic programming (DP) model for configuring module instances within an evolving family of products. Their DP-based approach is used to plan module introduction (i.e., which modules to introduce when) to maximize the total profit in a given planning horizon. An alternative classification of optimization approaches based on the extent of the optimization (i.e., module attributes, module combinations, or both) is discussed in Fujita (2002).

Based on the variety of optimization algorithms listed in the table, there does not appear to be a preferred algorithm for product family design. Linear and nonlinear programming algorithms (e.g., sequential linear programming, sequential quadratic programming, nonlinear programming, generalized reduced gradient) are employed by many researchers, as are derivative-free methods such as genetic algorithms (GAs), simulated annealing, pattern search, and branch and bound. When the design space is small enough, exhaustive search techniques (Hernandez et al., 2003) or orthogonal arrays (Chang \& Ward, 1995; Blackenfelt, 2000b) can be used to enumerate different combinations of parameter settings and modules. However, very few problems involve so few options that such an approach can be taken, and many researchers advocate the use of GAs for product platform design due to the combinatorial nature of the product family design problems (Gonzalez-Zugasti \& Otto, 2000; Fujita \& Yoshida, 2001; Li \& Azarm, 2002; D'Souza \& Simpson, 2003). Finally, algorithm choice is often mandated by the selected framework, for example, DecisionBased Design (DBD, Li \& Azarm, 2002), Target Cascading (Kokkolaras et al., 2002), 0-1 integer programming (Fujita et al., 1999), Physical Programming (Messac et al., 2002a), and the Compromise Decision Support Problem (Simpson et al., 1999).

Finally, these optimization approaches have been tested on a variety of product families as noted in the last column of the table. These product families range from 2 to 16 products, and include consumer products such as drills (see, e.g., Li \& Azarm, 2002), vacuum cleaners (Jiang \& Allada, 2001) and automobiles (Fellini, Kokkolaras, Michelena, et al., 2002; Kokkolaras et al., 2002); industrial products such as chillers (Hernandez et al., 2001) and flow control valves (Farrell \& Simpson, 2003); and complex systems such as aircraft (see, e.g., Fujita \& Yoshida, 2001; Simpson \& D'Souza, 2002) and spacecraft (see, e.g., Gonzalez-Zugasti et al., 2000). Detailed analyses for the universal electric motor problem can be found in Simpson, Maier, and Mistree, (2001); it has been used to benchmark a variety of optimization approaches, as noted in the table. The commercial aircraft problem found in Fujita et al. (1998) and Fujita and Yoshida (2001) uses aircraft analyses available in the literature in combination with their own models for design and development, facility, and production costs and a profit model for the manufacturer. The nail gun (Nelson et al., 2001), vacuum cleaner (Jiang \& Allada, 2001), and power screwdriver and electric knife (Rai \& Allada, 2002) examples are comprehensive as well. The automotive example used in Fellini, Kokkolaras, Michelana, et al. (2002) and Kokkolaras et al. (2002) is based on a detailed vehicle body structural model that is currently unavailable to the public; simpler models of the automotive vehicle frame can be in Fellini, Kokkolaras, Papalambros, et al. (2002) and Cetin and Saitou (2003). The analyses for the absorption chiller problem (Seepersad et al., 2000; Hernandez et al., 2001) are not publicly available either.

\section{AI IN PRODUCT PLATFORM DESIGN AND CUSTOMIZATION}

AI techniques for product platform design and customization lag behind optimization-based approaches; however, they have been successfully employed and shown great promise for automatic product configuration and automatic computer-aided design (CAD) modeling and geometry generation. Sabin and Weigel (1998) recently reviewed rulebased and model-based techniques for automatic product configuration; they state that the acquisition of the rules or constraints on which the reasoning depends is one of the major challenges in knowledge-based configuration systems. One such system is the Product Module Reasoning System developed by Rosen (1996), which reasons about sets of product architectures, translates design requirements into constraints on these sets, compares architecture modules from different viewpoints (e.g., material, connections, covers), and directly enumerates all feasible module combinations. His approach uses discrete mathematics (combinatorics and set theory) and provides the foundation for the Product Family Reasoning System developed by Siddique and Rosen $(2000,2001)$, which reasons about families of products in addition to individual product architectures. A configuration framework for mass customization of products that employs the Unified Modeling Language is 
introduced by Felfernig, Friedrich, and Jannach (2001) and Felfernig, Friedrich, et al. (2001). Claesson et al. (2001) use function-means-trees and a chromosome model to create configurable components that represent a parameterized set of design solutions; the concept is currently being deployed at Saab automobile to help control product variety. Finally, agent-based systems offer many advantages for concurrent product and process design and configuration (Shen et al., 2001), and agent-based approaches for modulebased product family design are being explored by some researchers (Allada \& Rai, 2002; Liang \& Huang, 2002; Rai \& Allada, 2002). However, these approaches are not yet as mature as the aforementioned optimization-based approaches.

Sabin and Weigel (1998) also discuss several case-based reasoning techniques for automatic product configuration. Such techniques generally involve eliciting customer requirements, retrieving a configuration from a pool of stored cases, and adapting the case to satisfy the new situation. A casebased approach for mass customization of goods was proposed by Tseng and Jiao (1997a). Their approach organizes information around the common features and platform within a product family architecture to facilitate case retrieval; adaptation of cases occurs either by reinstantiating the case if it is similar enough or by providing specific adaptation knowledge (configurational or topological) to modify aspects of the case. In Tseng and Jiao (1997c), a two-phase methodology is presented for recognizing patterns of functional requirements in similar existing products to help define new products.

To reduce data redundancy when modeling families of products, the Generic Bill-of-Material (GBOM) concept developed at the Eindhoven University of Technology (Hegge \& Wortmann, 1991; Erens et al., 1992; van Veen, 1992; Erens \& Hegge, 1994) allows all variants of a product family to be specified only once. Within a GBOM, the Primary Generic Product (PGP) represents the set of all variants of a particular primary product and Generic Subassembly Products (GSPs) describe the sets of subassemblies. Parameter values of the PGP are passed through the levels of the GBOM and are inherited by lower level GSPs. McKay et al. (1996) combine the GBOM concept with product modeling concepts and software to reduce data redundancy when considering multiple views (e.g., sales, manufacturing, assembly). Jiao and coauthors (2000) have extended the GBOM concept to include operations, and De Lit et al. (2001) use GBOMs to support assembly planning for families of products. Cheng et al. (2002) extended the GBOM concept for product family development within an extended enterprise.

Finally, grammar-based approaches have been developed for automating the generation of products within a family as well as automating the generation of CAD models. Agarwal and Cagan $(1997,2000)$ first popularized the approach, developing shape grammars to create a variety of coffeemakers. Siddique and Rosen (1999) use the same coffeemaker example to demonstrate a graph grammarbased approach for product platform design and instantiation. Within their graph grammar, graphs are used to represent the core function and structure (i.e., the platform), and grammars are used to specify the relationships between the core and the options (i.e., product variants). Meanwhile, Du et al. (2001b) have also developed a graph grammar-based approach for modeling product families. They use a Programmed Attribute Graph Grammar to specify the design space of the product family, which is then customized by varying modules according to a control diagram that captures the complex relationships and configuration constraints between modules. Their approach is extended in $\mathrm{Du}$ et al. (2002) by implementing a graph rewriting process to transform product family graphs into product variant graphs; a family of office chairs is used to illustrate their approach. Graph grammars are being used by Siddique and Shao (2001) to develop a Web-based system for product family reasoning and Siddique and Yanjiang (2002) describe a templatebased approach that automatically generates CAD models for each member in the product family. The approach was expanded to include parametric design, mating relationships, and modularity (Martinez-Larrosa \& Siddique, 2002), and is one of many Web-based approaches for customization that is discussed next.

\section{PRODUCT PLATFORMS AND (WEB-BASED) CUSTOMIZATION}

In addition to improving economies of scale and scope, a product platform can facilitate customization by enabling a variety of products to be quickly and easily developed to satisfy the needs and requirements of distinct market niches (Pine, 1993a). Although flooding the market with a variety of products derived from a platform may satisfy some customers by providing a substitute for customization, variety is not customization. Variety provides choices for customers but does not enable the customer to specify the product. A customized product, on the other hand, is designed to meet the specific needs of a particular customer; therefore, customers must be involved at one or more points in the product realization process for the product to be truly customized (see Fig. 5). This distinction is overlooked in much of the mass customization literature as noted by Duray et al. (2000), who study and classify companies that customize products based on the point of customer involvement. Customized products can be either made to order, tailored to order, assembled to order, or made to stock, each of which has different implications for product platform development and the associated information technologies needed to deliver that product (cf. Duray \& Milligan, 1999). Regardless of the stage of customer involvement, product platforms play an integral role in facilitating the product customization process. Tseng, Jiao, and coauthors have extensively studied the relationship between product family architecture and mass customization (Tseng et al., 1996; Tseng 


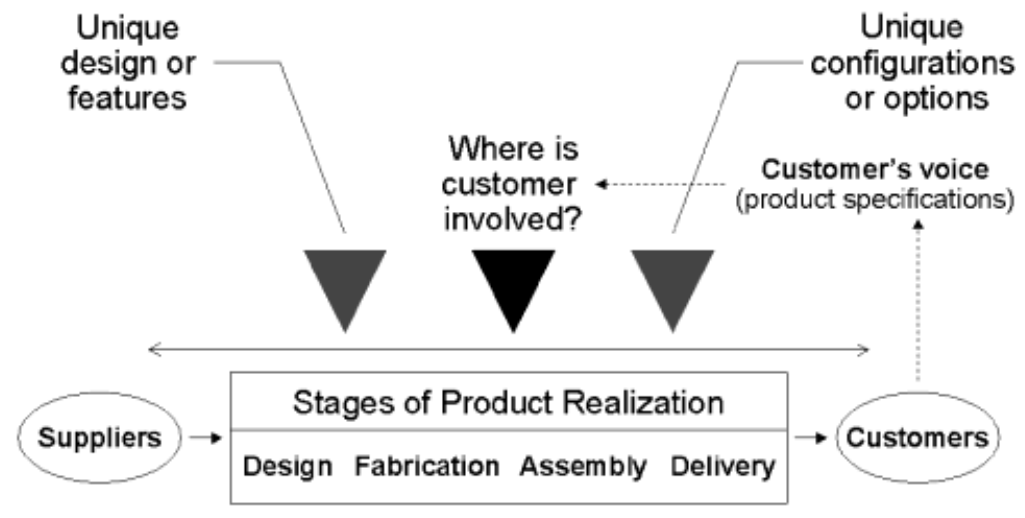

Fig. 5. Points of customer involvement for product customization. Adapted from Duray and Milligan (1999).

\& Jiao, 1998; Jiao \& Tseng, 1999, 2000; Du et al., 2000, 2001a), including a framework for virtual design for mass customization (Tseng et al., 1997).

Choi and Whinston (1999) assert that the "computermediated market will accelerate the process of customization through its technologies." Efficient information technology for product customization is one of several important research directions facing many of today's firms (Da Silveira et al., 2001; Zipkin, 2001). For instance, Webbased customization opens new paradigms for one to one marketing (Gilmore \& Pine, 1999), and it can provide valuable information for companies to improve customer demand estimates and determine whether to contract or expand product variety (Kotha, 1995).

Some prototypical Web-based systems for platform customization have been developed. For example, Simpson et al. (2003) created a Web-based system for customizing refiner plates for pulp and paper processing based on predefined platforms; the system exploits a parametric and feature-based modeling scheme for refiner plates developed in earlier work (Kulvatunyou et al., 2000). Flores et al. (2002) present a Web-based system for customizing coated steel belt sheaves, extending early parametric modeling capability developed in their lab (Rohm et al., 2000). A Web-based system that incorporates fuzzy geometric customization and fuzzy reasoning is presented in Chen et al. (2001) and demonstrated for customizing wineglasses and furniture. A Web-based knowledge system to support product family design has been developed by Zha and Lu (2002) and tested with a power supply product family. Researchers now recognize that suppliers are playing an increasingly important role in new product development, particularly in the automotive industry (MacDuffie et al., 1996; Gupta \& Krishnan, 1998a; Fisher et al., 1999), and Web-based systems are being developed to include suppliers in the design process (Huang, Huang, \& Mak, 2000; Huang \& Mak, 2000). Huang and his colleagues have also been developing systems to support collaborative product development and Design for X capabilities over the Internet (Huang \& Mak, 1999; Huang, Ski, \& Mak, 2000; Huang, Lee, \& Mak, 2001;
Huang, Shen, \& Mak, 2001). Finally, commercial software developers are staking their claims in this rapidly growing area of research. For instance, Windchill ${ }^{\circledast}$ DynamicDesignLink $^{\mathrm{TM}}$ enables dynamic, collaborative, Web-based product customization for design to order products (Parametric Technologies Corporation, 2002). The software allows customers to create custom products via the Web by providing guided product selection and configuration, automated product and process selection and generation, and integration with enterprise business systems.

\section{CLOSING REMARKS AND FUTURE RESEARCH DIRECTIONS}

As evidenced by this comprehensive review of product family and product platform design research, there has been considerable progress in planning, modeling, designing, and assessing product platforms and the families of products derived from them. Be it a module-based or a scale-based product family, there are now a variety of optimizationbased and AI-based techniques to support the design and decision making process. Although optimization-based approaches are more prevalent in the literature, AI-based techniques show great promise for product family design and customization. Web-based systems are also becoming more prominent to promote customer involvement in the product realization process and facilitate individual product customization via a well-defined product platform. Thanks to this flurry of research activity, this nascent field of study has matured rapidly in the past decade; however, considerable research is still needed to help bridge the gap between planning and managing families of products and designing and manufacturing them. Toward this end, several research thrusts are identified in the remainder of this section to help guide future efforts in this burgeoning field of research.

\subsection{Product family planning and platform development}

In an empirical study of 108 new product development projects, Tatikonda (1999) found that platform and deriva- 
tive projects are executed in a similar manner and do not differ in terms of project success even though they do differ in task characteristics (i.e., complexity and amount of new technology introduced). This suggests that some firms can manage single product and platform projects in similar ways, but system-level designers must still "address the problem of what product architecture should be used to deliver the different products while sharing parts and production steps across the products" (Robertson \& Ulrich, 1998, p. 21). Product family maps and the market segmentation grid support product family planning from a management perspective but offer little support to product and process engineers who must determine each product's architecture and the appropriate levels of platform commonality and component sharing within the family (cf. Maier \& Fadel, 2001). Information management systems to support product family development and foster component/module reuse are needed, and platform planning processes such as given in Robertson and Ulrich (1998) need to be developed, tested, and refined to help support engineering decision making during platform-based product development. Lessons learned from the set-based approaches employed successfully for years at Toyota (Ward et al., 1995) also show promise as models for product platform planning and development. Approaches for determining the extent and number of platforms to offer within a family (Seepersad et al., 2000, 2002; de Weck et al., 2003) also need to be further investigated.

\subsection{Quantifying the benefits and drawbacks of platform-based product development}

The metrics discussed in Section 4 provide surrogates for measuring the financial impact of platform development; however, quantifying the economic benefit of platformbased product development is important for strategic decision making (cf., Meyer et al., 1997; Schellhammer \& Karandikar, 2001). Some preliminary work in this area includes the use of activity-based costing to estimate the cost savings (Siddique \& Repphun, 2001) and reduction in development time (Siddique, 2001) for developing a hard disk drive spindle motor platform for a family of hard disks. Although many researchers espouse the benefits of platforms, platform-based approaches can impose additional costs on product development. The fixed costs of developing a product platform can be enormous, as evidenced by Ulrich and Eppinger (2000), who note that developing a product platform can cost 2-10 times more than a single product, and sharing components across low-end and highend products can increase unit variable costs due to overdesigned low-end products (Gupta \& Krishnan, 1998a; Fisher et al., 1999). In the automotive industry, Muffato (1999) found that up to $80 \%$ of total vehicle development cost is spent on platform development (including engine and transmission); others argue that platform development accounts for only $60 \%$ of these costs (Sundgren, 1999). Krishnan and Gupta (2001) develop a mathematical model to examine some of the costs of platform-based product development and find that platforms are not appropriate for extreme levels of market diversity or high levels of nonplatform scale economies.

\subsection{Modeling customer demand for product families}

As discussed in Section 7, incorporating customers in the product realization process is critical to successful platform customization, and recent work in DBD has revealed the importance of formulating a proper objective function to reflect the interests of both consumers and producers (Hazelrigg, 1996, 1998; Chen et al., 2000). Georgiopoulos et al. (2002) integrate engineering and business models for evaluating portfolio decisions involving a premium-compact and sport utility vehicle, and a formal framework for DBD was proposed by Hazelrigg $(1996,1998)$ and implemented for product design ( $\mathrm{Gu}$ et al., 2000; Li \& Azarm, 2000; Wassenaar \& Chen, 2001) and product line design (Li \& Azarm, 2002). Within their framework, Li and Azarm (2000, 2002) use conjoint analysis (see, e.g., Louviere, 1988; Green \& Srinivasan, 1990) to estimate customer demand within their DBD framework. Tseng and Du (1998) have also used conjoint analysis techniques for soliciting customer input for mass customized products that are based on a product family. Conjoint analysis has been widely used in marketing and management science for product platform design (Moore et al., 1999), product line design (see, e.g., Green \& Krieger, 1985; McBride \& Zufryden, 1988; Kohli \& Sukumar, 1990; Dobson \& Kalish, 1993), and product line redesign (Page \& Rosenbaum, 1987); however, Chen and Hausman (2000) note that many of these conjoint based approaches are mathematically intractable or NP-hard. Consequently, alternatives to conjoint analysis such as choicebased conjoint analysis (Azarm et al., 2003) and discrete choice analysis (Wassenaar \& Chen, 2001) are being investigated for use with DBD, but these techniques have not yet been extended for product family design.

\subsection{Design for manufacturing and assembly (DFMA)}

Most DFMA techniques have been developed for single products (cf. Bralla, 1999; van Vliet et al., 1999; Shah \& Wright, 2000; Boothroyd et al., 2002), and they do not effectively support product family design. For instance, creating modular product architectures runs counter to the DFMA principle of reducing part count by integrating parts, which often makes the architecture more integral; however, modularity can facilitate assembly. Conversely, increasing commonality will reduce the overall part count within a product family, and it will have the added benefit of delaying the point of product differentiation within the manufacturing and assembly process (see, e.g., Lee \& Tang, 1997; Gupta 
\& Krishnan, 1998b; He et al., 1998; Desai et al., 2001; Ma et al., 2002). Approaches for concurrent design of product families and assembly systems have been developed (Stadzisz \& Henrioud, 1995; Stadzisz et al., 1995; Martinez et al., 2000; Fouda et al., 2001). Kusiak (2000) discusses the importance of modular design in developing agile manufacturing systems, and an approach for optimizing modules for reconfigurable manufacturing systems was recently introduced by Yigit et al. (2002). These DFMA guidelines need to be formalized to support product family design and platformbased product development.

\subsection{Support for small- and medium-size manufacturers}

Although much of the research in product family design has focused on large corporations (e.g., Volkswagen, Boeing, Kodak, HP), product platforms and customization are becoming particularly important for small- and mediumsize firms. Small manufacturers lack an "adequately trained technical workforce" and do not have the "deep pockets" and "financial float" that is available in larger companies (Maupin \& Stauffer, 2000). Developing product platforms that can be leveraged across a variety of products is critical to remaining profitable, and tools such as Variant Mode and Effects Analysis, which have been tested at 10 mediumsized German automotive manufacturers, are useful in reducing product complexity and unwanted product variety (Schuh \& Tanner, 1998). Preliminary efforts to reengineer and improve commonality within a product family at small manufacturing firms can also be found in Maupin and Stauffer (2000), Berti et al. (2001), and Farrell and Simpson (2003).

\subsection{Overcoming organizational barriers to platform-based product development}

Designing a product platform and corresponding family of products embodies all of the challenges of product design while adding the complexity of coordinating the design of multiple products in an effort to increase commonality across the set of products without compromising their distinctiveness. For instance, Sanchez and Mahoney (1996) and Pederson (1999) discuss the impact of modularity and platforms, respectively, on the organization. Despite the benefits and advantages of platform-based product development, many companies remain hesitant to embrace product families and product platforms. For instance, despite the success and growth of the PC industry due to open, modular product architectures and product families (cf. Baldwin \& Clark, 1997; Christensen \& Verlinden, 2002), many aerospace organizations are resistant to such an approach because they fear losing their competitive edge in a relatively small market (cf. Caffrey et al., 2002a, 2002b). Erens (1997, p. 2) notes that "if sales engineers and designers focus on individual customer requirements, they feel that sharing components compromises the quality of their products."
Dismantling organizational complexity is the first step in reducing the negative effects of product variety (cf. Galsworth, 1994), and innovative approaches are needed to overcome the corporate inertia that develops within many companies. As an example, Chrysler's dramatic reorganization in 1988 around five platform teams (small car, large car, Jeep, truck, and minivan) with crossfunctional "tech clubs" (e.g., chassis, engine, HVAC, etc.) achieved significant reductions in development costs, lead time, and variable costs (Lutz, 1998). Organizational structures at other automotive companies (e.g., GM, Ford, Toyota, Volkswagen, Nissan, Fiat, Mazda, Honda) to promote platform development are documented and discussed in (Shimokawa et al., 1997; Cusumano \& Nobeoka, 1998). Meanwhile, Kotha (1995) examines an innovative approach used by Japan's National Bicycle Industrial Company for combining mass production and mass customization. Due to the impressive gains resulting from such innovations, we must strive to understand the organizational impact of platformbased product development better.

\section{ACKNOWLEDGMENTS}

This work was supported by National Science Foundation Career Grant DMI-0133923. Any opinions, findings, and conclusions or recommendations presented in this paper are those of the author and do not necessarily reflect the views of the National Science Foundation.

\section{REFERENCES}

Aboulafia, R. (2000). Airbus pulls closer to Boeing. Aerospace America $38(4), 16-18$.

Agarwal, M., \& Cagan, J. (1997). Shape grammars and their languages-A methodology for product design and product representation. Proc. ASME Design Engineering Technology Conf., Paper No. DETC97/DTM-3867.

Agarwal, M., \& Cagan, J. (2000). Shape grammar-base expert system for engineering design. In Artificial Intelligence in Design (Gero, J.S., Ed.), pp. 193-202. Worcester, MA: Kluwer.

Alford, D., Sackett, P., \& Nelder, G. (2000). Mass customisation-An automotive perspective. International Journal of Production Economics 65(1), 99-110.

Allada, V., \& Jiang, L. (2002). New modules launch planning for evolving modular product families. Proc. ASME Design Engineering Technology Conf., Paper No. DETC2002/DFM-34190.

Allada, V., \& Rai, R. (2002). Module-based multiple product design. IIE Annual Conf. Orlando, FL: IIE.

Allen, K.R., \& Carlson-Skalak, S. (1998). Defining product architecture during conceptual design. Proc. ASME Design Engineering Technology Conf., Paper No. DETC98/DTM-5650.

Anderson, D.M., \& Pine, B.J., II. (1997). Agile Product Development for Mass Customization. Chicago: Irwin Publishers.

Azarm, S., Brelsford, A., Kannan, P.K., \& Spencer, W. (2003). GOALI: Robust product design selection under uncertainty and for competitive advantage. Proc. 2003 NSF Design, Service and Manufacturing Grantees and Research Conf. (Reddy, R.G., Ed.), pp. 14-18. Birmingham, AL: University of Alabama.

Baker, K.R., Magazine, M.J., \& Nuttle, H.L.W. (1986). The effect of commonality on safety stock in a simple inventory model. Management Science 32(8), 982-988.

Baldwin, C.Y., \& Clark, K.B. (1997). Managing in an age of modularity. Harvard Business Review 75(5), 84-93.

Baldwin, C.Y., \& Clark, K.B. (2000). Design Rules: Volume 1. The Power of Modularity. Cambridge, MA: MIT Press. 
Berti, S., Germani, M., Mandorli, F., \& Otto, H.E. (2001). Design of product families-An example within a small and medium sized enterprise. 13th Int. Conf. Engineering Design (Culley, S., Duffy, A., McMahon, C., \& Wallace, K., Eds.), Glasgow, UK, pp. 507-514.

Blackenfelt, M. (2000a). Modularisation by relational matrices-A method for the consideration of strategic and functional aspects. 5th WDK Workshop on Product Structuring. Tampere, Finland: Tampere University of Technology.

Blackenfelt, M. (2000b). Profit maximisation while considering uncertainty by balancing commonality and variety using robust designThe redesign of a family of lift tables. Proc. ASME Design Engineering Technology Conf., Paper No. DETC2000/DFM-14013.

Blackenfelt, M., \& Sellgren, U. (2000). Design of robust interfaces in modular products. Proc. ASME Design Engineering Technology Conf., Paper No. DETC00/DAC-14486.

Boothroyd, G., Dewhurst, P., \& Knight, W. (2002). Product Design for Manufacture and Assembly. New York: Marcel Dekker.

Bralla, J.G., Ed. (1999). Design for Manufacturability Handbook. New York: McGraw-Hill.

Bremmer, R. (1999). Cutting-edge platforms. Financial Times Automotive World, Sept., 30-38.

Caffrey, R.T., Simpson, T.W., Henderson, R., \& Crawley, E. (2002a). The economic issues with implementing open avionics platforms for spacecraft. 20th AIAA Int. Communications Satellite Systems Conf. and Exhibit, Montreal, AIAA-2002-1870.

Caffrey, R.T., Simpson, T.W., Henderson, R., \& Crawley, E. (2002b). The strategic issues with implementing open avionics platforms for spacecraft. IEEE Aerospace Conf., IEEE-434-02. Big Sky, MT: IEEE.

Caffrey, R.T., Simpson, T.W., Henderson, R., \& Crawley, E. (2002c). The technical issues with implementing open avionics platforms for spacecraft. 40th AIAA Aerospace Sciences Meeting and Exhibit, Reno, NV, AIAA-2002-0319.

Cetin, O.L., \& Saitou, K. (2003). Decomposition-based assembly synthesis for structural modularity. ASME Journal of Mechanical Design.

Chandler, C., \& Williams, M. (1993). Strategic shift: A slump in car sales forces Nissan to start cutting swollen costs. Wall Street Journal, A1.

Chang, T.-S., \& Ward, A.C. (1995). Design-in-modularity with conceptual robustness. Advances in Design Automation (Azarm, S., Dutta, D., Eschenauer, H., Gilmore, B., McCarthy, M., \& Yoshimura, M., Eds.), Vol. 82-1, pp. 493-500. New York: ASME.

Chen, K.D., \& Hausman, W.H. (2000). Technical note: Mathematical properties of the optimal product line selection problem using choice-based conjoint analysis. Management Science 46(2), 327-332.

Chen, W., Lewis, K.E., \& Schmidt, L. (2000). Decision-based design: An emerging design perspective. Journal of Engineering Valuation \& Cost Analysis 3(2/3), 57-66

Chen, Y.H., Wang, Y.Z., \& Wong, M.H. (2001). A web-based fuzzy mass customization system. Journal of Manufacturing Systems 20(4), $280-287$.

Cheng, K., Hegge, H.M.H., Wortmann, J.C., \& Goosenaerts, J.B.M. (2002). Explore the knowledge distribution for making a family of products in an extended enterprise. In Advances in Concurrent Engineering (JardimGonçalves, R., Roy, R., \& Steiger-Garção, A., Eds.), pp. 633-643. Lisse: A.A. Balkema Publishers.

Child, P., Diederichs, R., Sanders, F.-H., \& Wisniowski, S. (1991). The management of complexity. Sloan Management Review 33(1), 73-80.

Chinnaiah, P.S.S., Kamarthi, S.V., \& Cullinane, T.P. (1998). Characterization and analysis of mass-customized production systems. International Journal of Agile Manufacturing 2(1), 93-118.

Choi, S.-Y., \& Whinston, A.B. (1999). The future of the digital economy. In Handbook on Electronic Commerce (Shaw, M., Blanning, R., Strader, T., \& Whinston, A., Eds.), pp. 25-52. New York: Springer.

Christensen, C., \& Verlinden, M. (2002). Disruption, disintegration, and the dissipation of differentiability. Industrial and Corporate Change 11(5), 955-993.

Claesson, A., Johannesson, H., \& Gedell, S. (2001). Platform product development: Product model-A system structure composed of configurable components. Proc. ASME Design Engineering Technology Conf., Paper No. DETC2001/DTM-21714.

Cohen, L. (1995). Quality Function Deployment: How to Make QFD Work for You. Reading, MA: Addison-Wesley.

Collier, D.A. (1981). The measurement and operating benefits of component part commonality. Decision Sciences 12(1), 85-96.

Coulter, S.L., McIntosh, M.W., Bras, B., \& Rosen, D.W. (1998). Identifi- cation of limiting factors for improving design modularity. Proc. ASME Design Engineering Technical Conferences, Paper No. DETC98/DFM5659.

Cusumano, M.A., \& Nobeoka, K. (1998). Thinking Beyond Lean. New York: Free Press.

Da Silveira, G., Borenstein, D., \& Fogliatto, F.S. (2001). Mass customization: Literature review and research directions. International Journal of Production Economics 72(1), 1-13.

Dahmus, J.B., Gonzalez-Zugasti, J.P., \& Otto, K.N. (2001). Modular product architecture. Design Studies 22(5), 409-424.

Dahmus, J.B., \& Otto, K.N. (2001). Incorporating lifecycle costs into product architecture decisions. Proc. ASME Design Engineering Technology Conf., Paper No. DETC2001/DAC-21110.

De Lit, P., L’Eglise, T., \& Delchambre, A. (2001). Functional entities: A concept to support product family and assembly system design. Proc. IEEE Int. Symp. Assembly and Task Planning, Fukuoka, Japan, pp. $160-165$.

Desai, P., Kekre, S., Radhakrishnan, S., \& Srinivasan, K. (2001). Product differentiation and commonality in design: Balancing revenue and cost drivers. Management Science 47(1), 37-51.

de Weck, O., Suh, E.S., \& Chang, D. (2003). Product family and platform portfolio optimization. Proc. ASME Design Engineering Technology Conf., Paper No. DETC2003/DAC-48721.

Dobson, G., \& Kalish, S. (1993). Heuristics for pricing and positioning a product-line using conjoint analysis and cost data. Management Science 39(2), 160-175.

D'Souza, B., \& Simpson, T.W. (2003). A genetic algorithm based method for product family design optimization. Engineering Optimization 35(1), $1-18$.

Du, X., Jiao, J., \& Tseng, M.M. (2000). Architecture of product family for mass customization. Proc. 2000 IEEE International Conf. Management of Innovation and Technology, Singapore, Vol. 1, pp. 437-443.

Du, X., Jiao, J., \& Tseng, M.M. (2001a). Architecture of product family: Fundamentals and methodology. Concurrent Engineering: Research \& Applications 9(4), 309-325.

Du, X., Jiao, J., \& Tseng, M.M. (2001b). Graph grammar based product variety modeling. Concurrent Engineering: Research \& Applications 10(2), 113-128.

Du, X., Jiao, J., \& Tseng, M.M. (2002). Product family modeling and design support: An approach based on graph rewriting systems. Artificial Intelligence for Engineering Design, Analysis and Manufacturing 16(2), 103-120.

Duray, R., \& Milligan, G.W. (1999). Improving customer satisfaction through mass customization. Quality Progress 32(8), 60-66.

Duray, R., Ward, P.T., Milligan, G.W., \& Berry, W.L. (2000). Approaches to mass customization: Configurations and empirical validation. Journal of Operations Management 18(6), 605-625.

Erens, F. (1997). Synthesis of variety: Developing product families. Ph.D. Dissertation. University of Technology, Eindhoven, The Netherlands.

Erens, F.J., \& Hegge, H.M.H. (1994). Manufacturing and sales co-ordination for product variety. International Journal of Production Economics 37(1), 83-99.

Erens, F.J., Hegge, H.M.H., \& Van Veen, E.A. (1992). Generative bills-ofmaterials: An overview. Proc. IFIP WG 5.7 Working Conf. on Integration in Production Management Systems (Pels, H.J., \& Wortmann, J.C., Eds.), p. 93. Amsterdam: Elsevier Science Publishers.

Ericsson, A., \& Erixon, G. (1999). Controlling Design Variants: Modular Product Platforms. New York: ASME.

Erixon, G. (1996). Design for modularity. In Design for $X$-Concurrent Engineering Imperatives (Huang, G. Q., Ed.), pp. 356-379. New York: Chapman \& Hall.

Farrell, R., \& Simpson, T.W. (2003). Product platform design to improve commonality in custom products. Journal of Intelligent Manufacturing.

Feitzinger, E., \& Lee, H.L. (1997). Mass customization at HewlettPackard: The power of postponement. Harvard Business Review 75(1), $116-121$.

Felfernig, A., Friedrich, G., \& Jannach, D. (2001). Conceptual modeling for configuration of mass-customizable products. Artificial Intelligence in Engineering 15(2), 165-176.

Felfernig, A., Friedrich, G., Jannach, D., \& Zanker, M. (2001). Intelligent support for interactive configuration of mass-customized products. Lecture Notes in Artificial Intelligence 2070, 746-756.

Fellini, R., Papalambros, P., \& Weber, T. (2000). Application of product platform design process to automotive powertrains. 8th AIAA/NASA/ 
USAF/ISSMO Symposium on Multidisciplinary Analysis and Optimization, Long Beach, CA, AIAA-2000-4849.

Fellini, R., Kokkolaras, M., Michelena, N., Papalambros, P., Saitou, K., Perez-Duarte, A., \& Fenyes, P.A. (2002). A sensitivity-based commonality strategy for family products of mild variation, with application to automotive body structures. 9th AIAA/ISSMO Symposium on Multidisciplinary Analysis and Optimization, Atlanta, GA, AIAA-20025610.

Fellini, R., Kokkolaras, M., Papalambros, P., \& Perez-Duarte, A. (2002). Platform selection under performance loss constraints in optimal design of product families. Proc. ASME Design Engineering Technology Conf., Paper No. DETC2002/DAC-34099.

Fisher, M.L., Ramdas, K., \& Ulrich, K.T. (1999). Component sharing in the management of product variety: A study of automotive braking systems. Management Science 45(3), 297-315.

Flores, R., Jensen, C.G., \& Shelley, J. (2002). A web enabled process for accessing customized parametric designs. Proc. ASME Design Engineering Technology Conf., Paper No. DETC2002/DAC-34078.

Fouda, P., Danloy, J., L'Eglise, T., De Lit, P., Rekiek, B., \& Delchambre, A. (2001). A heuristic to generate a precedence graph between components for a product family. IEEE International Symposium on Assembly and Task Planning, pp. 43-48. Fukuoka, Japan: IEEE.

Fujita, K. (2002). Product variety optimization under modular architecture. Computer-Aided Design 34(12), 953-965.

Fujita, K., \& Yoshida, H. (2001). Product variety optimization: Simultaneous optimization of module combination and module attributes. Proc. ASME Design Engineering Technology Conf., Paper No. DETC2001/ DAC-21058.

Fujita, K., Akagi, S., Yoneda, T., \& Ishikawa, M. (1998). Simultaneous optimization of product family sharing system structure and configuration. Proc. ASME Design Engineering Technology Conf., Paper No. DETC98/DFM-5722.

Fujita, K., Sakaguchi, H., \& Akagi, S. (1999). Product variety deployment and its optimization under modular architecture and module commonalization. Proc. ASME Design Engineering Technology Conf., Paper No. DETC99/DFM-8923.

Galsworth, G.D. (1994). Smart, Simple Design: Using Variety Effectiveness to Reduce Total Cost and Maximize Customer Selection. Essex Junction, VT: Omneo.

Georgiopoulos, P., Fellini, R., Sasena, M., \& Papalambros, P. (2002). Optimal design decisions in product portfolio valuation. Proc. ASME Design Engineering Technology Conf., Paper No. DETC2002/DAC-34097.

Gilmore, J.H., \& Pine, J.B., II, Eds. (1999). Markets of One. Boston: Harvard Business School Press.

Gonzalez-Zugasti, J.P., \& Otto, K.N. (2000). Modular platform-based product family design. Proc. ASME Design Engineering Technology Conf., Paper No. DETC-2000/DAC-14238.

Gonzalez-Zugasti, J.P., Otto, K.N., \& Baker, J.D. (2000). A method for architecting product platforms. Research in Engineering Design 12(2), 61-72.

Gonzalez-Zugasti, J.P., Otto, K.N., \& Baker, J.D. (2001). Assessing value for platformed product family design. Research in Engineering Design 13(1), 30-41.

Green, P.E., \& Krieger, A.M. (1985). Models and heuristics for product line selection. Marketing Science 4(1), 1-19.

Green, P.E., \& Srinivasan, V. (1990). Conjoint analysis in marketing: New developments with implications for research and practice. Journal of Marketing 54(4), 3-19.

Gu, X., Renaud, J.E., \& Ashe, L.M. (2000). Decision-based collaborative optimization under uncertainty. Proc. ASME Design Engineering Technology Conf., Paper No. DETC2000/DAC-14297.

Guo, F., \& Gershenson, J.K. (2003). Comparison of modular measurement methods based on consistency analysis and sensitivity analysis. Proc. ASME Design Engineering Technology Conf., Paper No. DETC2003/DTM-48634.

Gupta, S., \& Krishnan, V. (1998a). Integrated component and supplier selection for a product family. Production and Operations Management 8(2), 163-182.

Gupta, S., \& Krishnan, V. (1998b). Product family-based assembly sequence design methodology. IIE Transactions 30(10), 933-945.

Hazelrigg, G.A. (1996). Systems Engineering: An Approach to Informationbased Design. Upper Saddle River, NJ: Prentice Hall.

Hazelrigg, G.A. (1998). A framework for decision-based engineering design. ASME Journal of Mechanical Design 120(4), 653-658.
He, D., Kusiak, A., \& Tseng, T.-L. (1998). Delayed product differentiation: A design and manufacturing perspective. Computer-Aided Design 30(2), 105-113.

Hegge, H.M.H., \& Wortmann, J.C. (1991). Generic bill-of-material: A new product model. International Journal of Production Economics 23, $117-128$.

Hernandez, G., Simpson, T.W., Allen, J.K., Bascaran, E., Avila, L.F., \& Salinas, F. (2001). Robust design of families of products with production modeling and evaluation. ASME Journal of Mechanical Design 123(2), 183-190.

Hernandez, G., Allen, J.K., \& Mistree, F. (2002). Design of hierarchic platforms for customizable products. Proc. ASME Design Engineering Technology Conf., Paper No. DETC2002/DAC-34095.

Hernandez, G., Allen, J.K., \& Mistree, F. (2003). Platform design for customizable products as a problem of access in a geometric space. Engineering Optimization 35(3), 229-254.

Ho, T.-H., \& Tang, C.S., Eds. (1998). Product Variety Management: Research Advances. Boston: Kluwer Academic.

Holtta, K.M.M., \& Salonen, M.P. (2003). Comparing three different modularity methods. Proc. ASME Design Engineering Technology Conf., Paper No. DETC2003/DTM-48649.

Huang, C.-C., \& Kusiak, A. (1998). Modularity in design of products and systems. IEEE Transactions on Systems, Man and Cybernetics-Part A: Systems and Humans 28(1), 66-77.

Huang, C.-C., \& Kusiak, A. (1999). Synthesis of modular mechatronic products: A testability perspective. IEEE/ASME Transactions on Mechatronics 4(2), 119-132.

Huang, G.Q., Huang, J., \& Mak, K.L. (2000). Early supplier involvement in new product development on the Internet: Implementation perspectives. Concurrent Engineering: Research \& Applications 8(1), 40-49.

Huang, G.Q., Lee, S.W., \& Mak, K.L. (2001). Synchronised web applications for product development in the 21st century. International Journal of Advanced Manufacturing Technology 18(8), 605-613.

Huang, G.Q., \& Mak, K.L. (1999). Design for manufacturing and assembly on the Internet. Computers in Industry 38(1), 17-30.

Huang, G.Q., \& Mak, K.L. (2000). Webid: A web-based framework to support early supplier involvement in new product development. Robotics and Computer-Integrated Manufacturing 16(2), 169-179.

Huang, G.Q., Shen, B., \& Mak, K.L. (2001). Web applications in the product introduction process. International Journal of Advanced Manufacturing Technology 17(10), 775-782.

Huang, G.Q., Shi, J., \& Mak, K.L. (2000). Synchronized system for "Design for X" guidelines over the WWW. Journal of Materials Processing Technology 107(1-3), 71-78.

Huffman, C., \& Kahn, B.E. (1998). Variety for sale: Mass customization or mass confusion. Journal of Retailing 74(4), 491-513.

Ishii, K., Juengel, C., \& Eubanks, C.F. (1995). Design for product variety: Key to product line structuring. Proc. ASME Design Engineering Technology Conf., Boston, MA, Vol. 83-2, pp. 499-506.

Ishii, K., Lee, B.H., \& Eubanks, C.F. (1995). Design for product retirement and modularity based on technology life-cycle. ASME Manufacturing Science and Engineering (Kannatey-Asibu, E., Ed.), San Francisco, CA, MED-Vol. 2-2/MH-Vol. 3-2, pp. 921-933.

Jiang, L., \& Allada, V. (2001). Design for robustness of modular product families for current and future markets. Proc. ASME Design Engineering Technology Conf., Paper No. DETC2001/DFM-21177.

Jiao, J., \& Tseng, M.M. (1999). An information modeling framework for product families to support mass customization manufacturing. CIRP Annals 48(1), 93-98.

Jiao, J., \& Tseng, M.M. (2000). Understanding product family for mass customization by developing commonality indices. Journal of Engineering Design 11(3), 225-243.

Jiao, J., Tseng, M.M., Ma, Q., \& Zou, Y. (2000). Generic bill-of-materialsand-operations for high-variety production management. Concurrent Engineering: Research and Applications 8(4), 297-321.

Kim, K., \& Chhajed, D. (2000). Commonality in product design: Cost saving, valuation change and cannibalization. European Journal of Operational Research 125(3), 602-621.

Kimberly, W. (1999). Back to the future. Automotive Engineer 24(5), 62-64.

Kimura, F., Kato, S., Hata, T., \& Masuda, T. (2001). Product modularization for parts reuse in inverse manufacturing. CIRP Annals 50(1), 89-92.

Kobe, G. (1997). GM's seven platform global strategy. Automotive Industries 177, 50. 
Kohli, R., \& Sukumar, R. (1990). Heuristic for product line design using conjoint analysis. Management Science 36(12), 1464-1477.

Kokkolaras, M., Fellini, R., Kim, H.M., Michelena, N., \& Papalambros, P. (2002). Extension of the target cascading formulation to the design of product families. Structural and Multidiscipilnary Optimization 24(4), 293-301.

Kotha, S. (1995). Mass customization: Implementing the emerging paradigm for competitive advantage. Strategic Management Journal 16(3), $21-42$

Kota, S., Sethuraman, K., \& Miller, R. (2000). A metric for evaluating design commonality in product families. ASME Journal of Mechanical Design 122(4), 403-410.

Krishnan, V., \& Gupta, S. (2001). Appropriateness and impact of platformbased product development. Management Science 47(1), 52-68.

Kulvatunyou, B., Simpson, T.W., Halberg, E., \& Hodge, B. (2000). Parametric modeling approach for refiner plate design and production. AFS Transactions 108, 673-683.

Kusiak, A. (2000). Computational Intelligence in Design and Manufacturing. New York: Wiley.

Kusiak, A. (2002). Integrated product and process design: A modularity perspective. Journal of Engineering Design 13(1), 223-231.

Kusiak, A., \& Huang, C.-C. (1997). Design of modular digital circuits for testability. IEEE Transactions on Components, Packaging, and Manufacturing Technology 20(1), 48-57.

Lancaster, K. (1990). The economics of product variety. Marketing Science 9(3), 189-206.

Lee, H.L., \& Billington, C. (1994). Designing products and processes for postponement. In Management of Design: Engineering and Management Perspective (Dasu, S., \& Eastman, C., Eds.), pp. 105-122. Boston, MA: Kluwer Academic Publishers

Lee, H.L., \& Tang, C.S. (1997). Modeling the costs and benefits of delayed product differentiation. Management Science 43(1), 40-53.

Lehnerd, A.P. (1987). Revitalizing the manufacture and design of mature global products. In Technology and Global Industry: Companies and Nations in the World Economy (Guile, B.R., \& Brooks, H., Eds.), pp. 49-64. Washington, DC: National Academy Press.

Li, H., \& Azarm, S. (2000). Product design selection under uncertainty and with competitive advantage. ASME Journal of Mechanical Design 122(4), 411-418.

Li, H., \& Azarm, S. (2002). An approach for product line design selection under uncertainty and competition. ASME Journal of Mechanical Design 124(3), 385-392.

Liang, W.-Y., \& Huang, C.-C. (2002). Agent-based collaboration information system of product development. International Journal of Information Management 22(3), 211-224.

Louviere, J.J. (1988). Conjoint analysis modeling of stated preferences: A review of theory, methods, recent developments, and external validity. Journal of Transport Economics and Policy 22, 93-99.

Lutz, R.A. (1998). Guts: The Seven Laws of Business that Made Chrysler the World's Hottest Car Company. New York: Wiley.

Ma, S., Wang, W., \& Liu, L. (2002). Commonality and postponement in multistage assembly systems. European Journal of Operational Research 142(3), 523-538.

MacDuffie, J.P., Sethuraman, K., \& Fisher, M.L. (1996). Product variety and manufacturing performance: Evidence from the international automotive assembly plant study. Management Science 42(3), 350-369.

Maier, J.R.A., \& Fadel, G. (2001). Strategic decisions in the early stages of product family design. Proc. ASME Design Engineering Technology Conf., Paper No. DETC2001/DFM-21200.

Martin, M., \& Ishii, K. (1996). Design for variety: A methodology for understanding the costs of product proliferation. ASME Design Engineering Technology Conf., Paper No. 96-DETC/DTM-1610.

Martin, M.V., \& Ishii, K. (1997). Design for variety: Development of complexity indices and design charts. Proc. ASME Design Engineering Technology Conf., Paper No. DETC97/DFM-4359.

Martin, M.V., \& Ishii, K. (2002). Design for variety: Developing standardized and modularized product platform architectures. Research in Engineering Design 13(4), 213-235.

Martinez, M.T., Favrel, J., \& Ghodous, P. (2000). Product family manufacturing plan generation and classification. Concurrent Engineering: Research \& Applications 8(1), 12-23.

Martinez-Larrosa, J.A., \& Siddique, Z. (2002). CAD support for product family design using parametrics, mating relationships, and modularity.
In Advances in Concurrent Engineering (Jardim-Gonçalves, R., Roy, R., \& Steiger-Garção, A., Eds.), pp. 535-543. Lisse: A.A. Balkema Publishers.

Mather, H. (1995). Product variety-Friend or foe? 38th American Production \& Inventory Control Society Int. Conf., Orlando, FL, pp. 378-381.

Mattson, C.A., \& Magleby, S.P. (2001). The influence of product modularity during concept selection of consumer products. Proc. ASME Design Engineering Technology Conf., Paper No. DETC2001/DTM21712.

Maupin, A.J., \& Stauffer, L.A. (2000). A design tool to help small manufacturers reengineer a product family. Proc. ASME Design Engineering Technology Conf., Paper No. DETC2000/DTM-14568.

McAdams, D.A., Stone, R.B., \& Wood, K.L. (1999). Functional independence and product similarity based on customer needs. Research in Engineering Design 11(1), 1-19.

McAdams, D.A., \& Wood, K.L. (2002). A quantitative similarity metric for design-by-analogy. ASME Journal of Mechanical Design 124(2), $173-182$.

McBride, R.D., \& Zufryden, F.S. (1988). An integer programming approach to the optimal product line selection problem. Marketing Science 7(2), 126-140.

McDermott, C.M., \& Stock, G.N. (1994). The use of common parts and designs in high-tech industries: A strategic approach. Production \& Inventory Management Journal 35(3), 65-68.

McGrath, M.E. (1995). Product Strategy for High-Technology Companies. New York: Irwin Professional Publishing.

McKay, A., Erens, F., \& Bloor, M.S. (1996). Relating product definition and product variety. Research in Engineering Design 8(2), 63-80.

Messac, A., Martinez, M.P., \& Simpson, T.W. (2002a). Effective product family design using physical programming. Engineering Optimization 34(3), 245-261.

Messac, A., Martinez, M.P., \& Simpson, T.W. (2002b). A penalty function for product family design using physical programming. ASME Journal of Mechanical Design 124(2), 164-172.

Meyer, M.H. (1997). Revitalize your product lines through continuous platform renewal. Research Technology Management 40(2), 17-28.

Meyer, M.H., \& Dalal, D. (2002). Managing platform architectures and manufacturing processes for nonassembled products. Journal of Production Innovation Management 19(4), 277-293.

Meyer, M.H., \& DeTore, A. (2001). Perspective: Creating a platformbased approach for developing new services. Journal of Production Innovation Management 18(3), 188-204.

Meyer, M.H., \& Lehnerd, A.P. (1997). The Power of Product Platforms: Building Value and Cost Leadership. New York: Free Press.

Meyer, M.H., \& Utterback, J.M. (1993). The product family and the dynamics of core capability. Sloan Management Review 34, 29-47.

Meyer, M.H., Tertzakian, P., \& Utterback, J.M. (1997). Metrics for managing research and development in the context of the product family. Management Science 43(1), 88-111.

Moore, W.L., Louviere, J.J., \& Verma, R. (1999). Using conjoint analysis to help design product platforms. Journal of Production and Innovation Management 16(1), 27-39.

Muffatto, M. (1999). Introducing a platform strategy in product development. International Journal of Production Economics 60-61, $145-153$.

Naughton, K., Thornton, E., Kerwin, K., \& Dawley, H. (1997). Can Honda build a world car? Business Week 100(7).

Nayak, R.U., Chen, W., \& Simpson, T.W. (2002). A variation-based method for product family design. Engineering Optimization 34(1), 65-81.

Nelson, S.A., II, Parkinson, M.B., \& Papalambros, P.Y. (2001). Multicriteria optimization in product platform design. ASME Journal of Mechanical Design 123(2), 199-204.

Newcomb, P.J., Bras, B., \& Rosen, D.W. (1998). Implications of modularity on product design for the life cycle. ASME Journal of Mechanical Design 120(3), 483-490.

O'Grady, P. (1999). The Age of Modularity. Iowa City, IA: Adams and Steele.

Ortega, R., Kalyan-Seshu, U., \& Bras, B. (1999). A decision support model for the life-cycle design of a family of oil filters. Proc. ASME Design Engineering Technology Conf., Paper No. DETC99/DAC-8612.

Otto, K. (2001). A process of modularizing product families. 13th Int. Conf. Engineering Design (Culley, S., Duffy, A., McMahon, C., \& Wallace, K., Eds.), Glasgow, UK, pp. 523-530. 
Otto, K.N., \& Wood, K.L. (2001). Product Design: Techniques in Reverse Engineering and New Product Development. Upper Saddle River, NJ: Prentice Hall.

Page, A.L., \& Rosenbaum, H.F. (1987). Redesigning product lines with conjoint analysis: How Sunbeam does it. Journal of Production and Innovation Management 4(2), 120-137.

Pahl, G., \& Beitz, W. (1996). Engineering Design: A Systematic Approach, 2nd rev. ed. New York: Springer-Verlag.

Parametric Technologies Corporation. (2002). Using Windchill ${ }^{\circledR}$ DynamicDesignLink $^{\mathrm{TM}}$ to enable flexible and cost efficient mass customization through design to order, White Paper. Needham, MA: Parametric Technologies Corporation.

Pederson, P. (1999). Organisational impacts of platform based product development. 12th Int. Conf. on Engineering Design, Vol. 3, pp. 1507-1512.

Pessina, M.W., \& Renner, J.R. (1998). Mass customization at Lutron Electronics-A total company process. Agility \& Global Competition 2(2), 50-57.

Pimmler, T.U., \& Eppinger, S.D. (1994). Integration analysis of product decompositions. Proc. ASME Design Engineering Technology Conf., Vol. 68, pp. 343-351.

Pine, J.B., II. (1993a). Mass Customization: The New Frontier in Business Competition. Boston: Harvard Business School Press.

Pine, J.B., II. (1993b). Standard modules allow mass customization at Bally Engineering Structures. Planning Review 21(4), 20-22.

Rai, R., \& Allada, V. (2002). Modular Product Family Design: AgentBased Pareto-Optimization and Post Optimal Analysis, Working Paper. Rolla, MO: Engineering Management Department, University of Missouri-Rolla.

Riitahuta, A., \& Andreasen, M.M. (1999). Modularisation support of life cycle management. Proc. First Int. Conf. on Environmentally Conscious Design and Inverse Manufacturing, pp. 316-321. Tokyo: IEEE.

Robertson, D., \& Ulrich, K. (1998). Planning product platforms. Sloan Management Review 39(4), 19-31.

Rohm, T., III, Jones, C.L., Tucker, S.S., \& Jensen, C.G. (2000). Parametric engineering design tools and applications. Proc. ASME Design Engineering Technology Conf., Paper No. DETC2000/DAC-14275.

Rosen, D.W. (1996). Design of modular product architectures in discrete design spaces subject to life cycle issues. Advances in Design Automation (Dutta, D., Ed.), Paper No. 96-DETC/DAC-1485.

Rothwell, R., \& Gardiner, P. (1990). Robustness and product design families. In Design Management: A Handbook of Issues and Methods (Oakley, M., Ed.), pp. 279-292. Cambridge, MA: Basil Blackwell Inc.

Rutenberg, D.P. (1969). Design commonality to reduce multi-item inventory: Optimal depth of a product line. Operations Research 19(2), 491-509.

Sabbagh, K. (1996). Twenty-First Century Jet: The Making and Marketing of the Boeing 777. New York: Scribner.

Sabin, D., \& Weigel, R. (1998). Product configuration frameworks-A survey. IEEE Intelligent Systems 13(4), 42-49.

Sanchez, R., \& Mahoney, J.T. (1996). Modularity, flexibility, and knowledge management in product organization design. Strategic Management Journal 17, 63-76.

Sand, J.C., Gu, P., \& Watson, G. (2002). Home: House of modular enhancement-A tool for modular product redesign. Concurrent Engineering: Research \& Applications 10(2), 153-164.

Sanderson, S.W., \& Uzumeri, M. (1997). Managing Product Families. Chicago: Irwin.

Schellhammer, W., \& Karandikar, H. (2001). Metrics for executing a product platform strategy. 13th Int. Conf. Engineering Design (Culley, S., Duffy, A., McMahon, C., \& Wallace, K., Eds.), Glasgow, UK, pp. 531-538.

Schilling, M.A. (2000). Toward a general modular systems theory and its applications to interfirm product modularity. Academy of Management Review 25(2), 312-334.

Schuh, G., \& Tanner, H.R. (1998). Mastering variant variety using the variant mode and effects analysis. Proc. ASME Design Engineering Technology Conf., Paper No. DETC98/DFM-5736.

Seepersad, C.C., Hernandez, G., \& Allen, J.K. (2000). A quantitative approach to determining product platform extent. Proc. ASME Design Engineering Technology Conf., Paper No. DETC2000/DAC-14288.

Seepersad, C.C., Mistree, F., \& Allen, J.K. (2002). A quantitative approach for designing multiple product platforms for an evolving portfolio of products. Proc. ASME Design Engineering Technology Conf., Paper No. DETC2002/DAC-34096.

Shah, J.J., \& Wright, P.K. (2000). Developing theoretical foundations for DfM. Proc. ASME Design Engineering Technology Conf., Paper No. DETC2000/DFM-14015.

Sharman, D.M., Yassine, A.A., \& Carlile, P. (2002). Characterising modular architectures. Proc. ASME Design Engineering Technology Conf. Paper No. DETC2002/DTM-34024.

Shen, W., Norrie, D.H., \& Barthès, J.-P.A. (2001). Multi-Agent Systems for Concurrent Intelligent Design and Manufacturing. New York: Taylor \& Francis.

Shimokawa, K., Jurgens, U., \& Fujimoto, T., Eds. (1997). Transforming Automobile Assembly: Experience in Automation and Work Organization. New York: Springer.

Shirley, G.V. (1990). Models for managing the redesign and manufacture of product sets. Journal of Manufacturing and Operations Management 3(2), 85-104.

Siddique, Z. (2001). Estimating reduction in development time for implementing a product platform approach. Proc. ASME Design Engineering Technology Conf., Paper No. DETC2001/CIE-21238.

Siddique, Z., \& Repphun, B. (2001). Estimating cost savings when implementing a product platform approach. Concurrent Engineering: Research \& Applications 9(4), 285-294.

Siddique, Z., \& Rosen, D.W. (1999). Product platform design: A graph grammar approach. Proc. ASME Design Engineering Technology Conf., Paper No. DETC99/DTM-8762.

Siddique, Z., \& Rosen, D.W. (2000). Product family configuration reasoning using discrete design spaces. Proc. ASME Design Engineering Technology Conf., Paper No. DETC2000/DTM-14666.

Siddique, Z., \& Rosen, D.W. (2001). On combinatorial design spaces for the configuration design of product families. Artificial Intelligence for Engineering Design, Analysis and Manufacturing 15(2), 91-108.

Siddique, Z., \& Shao, Z. (2001). A graph grammar based approach for development of an internet-based product family information system. Proc. ASME Design Engineering Technology Conf., Paper No. DETC2001/CIE-21280.

Siddique, Z., \& Yanjiang, Z. (2002). Automatic generation of product family member CAD models supported by a platform using a template approach. Proc. ASME Design Engineering Technology Conf., Paper No. DETC2002/CIE-34407.

Siddique, Z., Rosen, D.W., \& Wang, N. (1998). On the applicability of product variety design concepts to automotive platform commonality. Proc. ASME Design Engineering Technology Conf., Paper No. DETC98/DTM-5661.

Simpson, T.W., \& D’Souza, B. (2002). Assessing variable levels of platform commonality within a product family using a multiobjective genetic algorithm. 9th AIAA/ISSMO Symposium on Multidisciplinary Analysis and Optimization, Atlanta, GA, Paper AIAA-2002-5427.

Simpson, T.W., Chen, W., Allen, J.K., \& Mistree, F. (1999). Use of the robust concept exploration method to facilitate the design of a family of products. In Simultaneous Engineering: Methodologies \& Applications (Roy, U., Usher, J.M., \& Parsaei, H.R., Eds.), pp. 247-278. Amsterdam: Gordon \& Breach Science Publishers.

Simpson, T.W., Maier, J.R.A., \& Mistree, F. (2001). Product platform design: Method and application. Research in Engineering Design 13(1), 2-22.

Simpson, T.W., Seepersad, C.C., \& Mistree, F. (2001). Balancing commonality and performance within the concurrent design of multiple products in a product family. Concurrent Engineering: Research \& Applications 9(3), 177-190.

Simpson, T.W., Nanda, J., Halbe, S., Umapathy, K., \& Hodge, B. (2003) Development of a framework for web-based product platform customization. ASME Journal of Computing and Information Science in Engineering 3(2), 119-129.

Stadzisz, P.C., \& Henrioud, J.M. (1995). Integrated design of product families and assembly systems. Proc. IEEE Int. Conf. Robotics \& Automation, Nagoya, Japan, Vol. 2, pp. 1290-1295.

Stadzisz, P.C., Henrioud, J.M., \& Bourjault, A. (1995). Concurrent development of product families and assembly systems. Proc. IEEE Int Symp. Assembly \& Task Planning, Pittsburgh, PA, pp. 327-332.

Stake, R.B., \& Blackenfelt, M. (2000). Modularisation by cluster analysis-Capturing both functional and strategic aspects. NordDesign Seminar, Copenhagen.

Stalk, G., Jr., \& Webber, A.M. (1993). Japan's dark side of time. Harvard Business Review 71(4), 93-102. 
Stone, R.B., Wood, K.L., \& Crawford, R.H. (2000a). A heuristic method to identify modules from a functional description of a product. Design Studies 21(1), 5-31.

Stone, R.B., Wood, K.L., \& Crawford, R.H. (2000b). Using quantitative functional models to develop product architectures. Design Studies 21(3), 239-260.

Sudjianto, A., \& Otto, K.N. (2001). Modularization to support multiple brand platforms. Proc. ASME Design Engineering Technology Conf., Paper No. DETC2001/DTM-21695.

Suh, N.P. (1990). Principles of Design. Oxford, UK: Oxford University Press.

Sundgren, N. (1999). Introducing interface management in new product family development. Journal of Product Innovation Management 16(1), 40-51.

Tatikonda, M.V. (1999). An empirical study of platform and derivative product development projects. Journal of Product Innovation Management 16(1), 3-26.

Thomas, L.D. (1992). Functional implications of component commonality in operational systems. IEEE Transactions on Systems, Man and Cybernetics 22(3), 548-551.

Trelevan, M., \& Wacker, J.G. (1987). The sources, measurements, and managerial implications of process commonality. Journal of Operations Management 7(1-2), 11-25.

Tseng, M.M., \& Du, X. (1998). Design by customers for mass customization products. CIRP Annals 47(1), 103-106.

Tseng, M.M., \& Jiao, J. (1997a). Case-based evolutionary design for mass customization. Computers in Industrial Engineering 33(1-2), 319-323.

Tseng, M.M., \& Jiao, J. (1997b). A module identification approach to the electrical design of electronic products by clustering analysis of the design matrix. Computers \& Industrial Engineering 33(1-2), 229-233.

Tseng, M.M., \& Jiao, J. (1997c). A variant approach to product definition by recognizing functional requirement patterns. Journal of Engineering Design 8(4), 329-340.

Tseng, M.M., \& Jiao, J. (1998). Design for mass customization by developing product family architecture. Proc. ASME Design Engineering Technology Conf., Paper No. DETC98/DTM-5717.

Tseng, M.M., Jiao, J., \& Merchant, M.E. (1996). Design for mass customization. CIRP Annals 45(1), 153-156.

Tseng, M.M., Jiao, J., \& Su, C.-J. (1997). A framework of virtual design for product customization. Proc. 6th Int. Conf. on Emerging Technologies and Factory Automation, pp. 7-14. Los Angeles: IEEE.

Ulrich, K. (1995). The role of product architecture in the manufacturing firm. Research Policy 24(3), 419-440.

Ulrich, K.T., \& Eppinger, S.D. (2000). Product Design and Development, 2nd ed. New York: McGraw-Hill.

Umeda, Y., Shimomura, Y., Yoshioka, M., \& Tomiyama, T. (1999). A proposal of design methodology for upgradable products. Proc. ASME Design Engineering Technology Conf., Paper No. DETC99/DFM-8969.

Vakharia, A.J., Parmenter, D.A., \& Sanchez, S.M. (1996). The operating impact of parts commonality. Journal of Operations Management 14(1), 3-18.

van Veen, E. (1992). Modeling Product Structures by Generic Bills-ofMaterials. Amsterdam: Elsevier Science Publishers.

van Vliet, J.W., van Luttervelt, C.A., \& Kals, H.J.J. (1999). State-of-the-art report on design for manufacturing. Proc. ASME Design Engineering Technology Conf., Paper No. DETC99/DFM-8970.

Wacker, J.G., \& Trelevan, M. (1986). Component part standardization: An analysis of commonality sources and indices. Journal of Operations Management 6(2), 219-244.
Ward, A., Liker, J.K., Cristiano, J.J., \& Sobek, D.K. (1995). The second Toyota paradox: How delaying decisions can make better cars faster. Sloan Management Review 36(3), 43-61.

Wassenaar, H.J., \& Chen, W. (2001). An approach to decision-based design. Proc. ASME Design Engineering Technology Conf., Paper No. DETC2001/DTM-21683.

Wheelwright, S.C., \& Clark, K.B. (1992). Creating project plans to focus product development. Harvard Business Review 70(2), 70-82.

Wheelwright, S.C., \& Clark, K.B. (1995). Leading Product Development. New York: Free Press.

Wheelwright, S.C., \& Sasser, W.E., Jr. (1989). The new product development map. Harvard Business Review 67(3), 112-125.

Whitney, D.E. (1993). Nippondenso Co. Ltd: A case study of strategic product design. Research in Engineering Design 5(1), 1-20.

Wilhelm, B. (1997). Platform and modular concepts at VolkswagenTheir effect on the assembly process. In Transforming Automobile Assembly: Experience in Automation and Work Organization (Shimokawa, K., Jürgens, U., \& Fujimoto, T., Eds.), pp. 146-156. New York: Springer.

Womack, J.P., Jones, D.T., \& Roos, D. (1990). The Machine that Changed the World. New York: Rawson Associates.

Wortmann, J.C., Muntslag, D.R., \& Timmermans, P.J.M., Eds. (1997). Customer-Driven Manufacturing. New York: Chapman \& Hall.

Yigit, A.S., Ulsoy, A.G., \& Allahverdi, A. (2002). Optimizing modular product design for reconfigurable manufacturing. Journal of Intelligent Manufacturing 13(4), 309-316.

Yu, J.S., Gonzalez-Zugasti, J.P., \& Otto, K.N. (1999). Product architecture definition based upon customer demand. ASME Journal of Mechanical Design 121(3), 329-335.

Zamirowksi, E.J., \& Otto, K.N. (1999). Identifying product portfolio architecture modularity using function and variety heuristics. Proc. ASME Design Engineering Technology Conf., Paper No. DETC99/DTM-8760.

Zha, X.F., \& Lu, W.F. (2002). Knowledge intensive support for product family design. Proc. ASME Design Engineering Technology Conf., Paper No. DETC2002/DAC-34098.

Zhang, Y., Gershenson, J.K., \& Allamneni, S. (2001). Determining relationships between modularity and cost in product retirement. Proc. ASME Design Engineering Technology Conf., Paper No. DETC2001/ DTM-21686.

Zipkin, P. (2001). The limits of mass customization. Sloan Management Review 42(3), 81-87.

Timothy W. Simpson is an Associate Professor of Mechanical and Industrial Engineering at Pennsylvania State University. He received a BS degree in mechanical engineering from Cornell University in 1994 and MS and PhD degrees in 1995 and 1998, respectively, in mechanical engineering from the Georgia Institute of Technology. Timothy is a member of ASME, AIAA, and ASEE and is Director of the Product Realization Minor in the College of Engineering at Penn State. Dr. Simpson's research and teaching interests include product family and product platform design, engineering optimization, and Web-based customization. 